\title{
Distribution and temporal variation of mega-fauna at the Regab pockmark (Northern Congo Fan), based on a comparison of videomosaics and geographic information systems analyses
}

\author{
Yann Marcon ${ }^{1, *}$, Heiko Sahling ${ }^{1}$, Anne-Gaëlle Allais ${ }^{2}$, Gerhard Bohrmann $^{1}$, Karine Olu $^{3}$
}

\author{
${ }^{1}$ Faculty of Geosciences, MARUM - Center for Marine Environmental Sciences, University of Bremen, Bremen, \\ Germany \\ ${ }^{2}$ Département Infrastructures Marines et Numériques, Ifremer, IFREMER Centre de Méditerranée, La Seyne sur \\ Mer, France \\ ${ }^{3}$ Ifremer, REM, Laboratoire Environnement Profond (EEP-LEP), IFREMER Centre de Brest, Plouzané, France
}

*: Corresponding author : Yann Marcon, ymarcon@marum.de

\begin{abstract}
:
The Regab pockmark is a large cold seep area located $10 \mathrm{~km}$ north of the Congo deep sea channel at about $3160 \mathrm{~m}$ water depth. The associated ecosystem hosts abundant fauna, dominated by chemosynthetic species such as the mussel Bathymodiolus aff. boomerang, vestimentiferan tubeworm Escarpia southwardae, and vesicomyid clams Laubiericoncha chuni and Christineconcha regab. The pockmark was visited during the West African Cold Seeps (WACS) cruise with RV Pourquoi Pas? in February 2011, and a $14,000-\mathrm{m}^{2}$ high-resolution videomosaic was constructed to map the most populated area and to describe the distribution of the dominant megafauna (mussels, tubeworms and clams). The results are compared with previous published works, which also included a videomosaic in the same area of the pockmark, based on images of the BIOZAIRE cruise in 2001. The 10-year variation of the faunal distribution is described and reveals that the visible abundance and distribution of the dominant megafaunal populations at Regab have not changed significantly, suggesting that the overall methane and sulfide fluxes that reach the faunal communities have been stable. Nevertheless, small and localized distribution changes in the clam community indicate that it is exposed to more transient fluxes than the other communities. Observations suggest that the main megafaunal aggregations at Regab are distributed around focused zones of high flux of methane-enriched fluids likely related to distinct smaller pockmark structures that compose the larger Regab pockmark. Although most results are consistent with the existing successional models for seep communities, some observations in the distribution of the Regab mussel population do not entirely fit into these models. This is likely due to the high heterogeneity of this site formed by the coalescence of several pockmarks. We hypothesize that the mussel distribution at Regab could also be controlled by the occurrence of zones of both intense methane fluxes and reduced efficiency of the anaerobic oxidation of methane possibly limiting tubeworm colonization.
\end{abstract}

Keywords: Cold seep ; Fauna ; Mosaic ; Pockmark ; Regab ; temporal variation 


\section{1. Introduction}

2 Cold-seep ecosystems have been identified along active and passive margins

3 worldwide, and are known to host rich and abundant chemosynthetic communities

4 (Sibuet \& Olu-Le Roy 2002). Many studies have described the distribution of the

5 dominant faunal assemblages in relation to their environment in several cold seeps

6 systems (Sibuet \& Olu-Le Roy 2002, MacDonald et al. 2003, Olu-Le Roy et al.

7 2007a, Jerosch et al. 2007, Lessard-Pilon et al. 2010), and cold seeps are usually

8 considered to provide more stable environments than hydrothermal vents. Although

9 some decadal-scale stability of vent fauna was sometimes observed (Desbruyères

10 1998, Copley et al. 2007, Cuvelier et al. 2011), several studies about temporal

11 variation of vent communities suggested that hydrothermal vents can be highly

12 dynamic environments (Hessler et al. 1988, Shanks 1995, Shank et al. 1998,

13 Mullineaux et al. 2000), especially when considering smaller spatial and temporal

14 scales (Cuvelier et al. 2011). Existing observations of individual taxonomic groups at

15 cold seeps revealed very slow growth rates and extremely long lifetimes likely related

16 to slow and steady fluxes of reduced compounds (Nix et al. 1995, Fisher et al. 1997,

17 Smith et al. 2000, Bergquist et al. 2000). For instance, some tubeworm aggregations

18 were estimated to be at least 250 years old (Fisher et al. 1997, Bergquist et al. 2000),

19 and ages of several hundreds of years have been assessed for Bathymodiolus

20 childressi (Smith et al. 2000).

21 Up to now, very few works focused on the temporal variation of the faunal

22 distribution (Lessard-Pilon et al. 2010) in a cold seep environment. Such information

23 is not only important to increase our knowledge about the community dynamics, but it

24 also allows better understanding the dynamics of the venting activity. Indeed,

25 chemosynthetic communities are highly dependent on their environment, primarily 
1 because distribution patterns of the dominant symbiont-bearing, habitat-creating taxa

2 are linked to methane and sulfide levels and fluxes, and substrata (Sahling et al. 2002,

3 MacDonald et al. 2003, Levin et al. 2003, Bergquist et al. 2005, Mau et al. 2006, Olu-

4 Le Roy et al. 2007a). Distribution changes therefore could also reflect changes in the

5 venting activity.

6 Bergquist et al. (2003b) and Cordes et al. (2005b) suggested that community changes

7 could be also time-related, and proposed a succession model for Gulf of Mexico seep

8 communities, in which mussel beds become replaced by tubeworm communities as

9 carbonate precipitates in the sediments. With time, tubeworm communities then

10 contribute to reducing methane and sulfide availability at the sediment/water

11 interface, thus leading to changes in the associated communities, by allowing non-

12 endemic species to venture and compete with chemosynthetic species.

13 Whatever the cause of flux change, mussel population mortality and movements are

14 considered to reflect changes in seepage flow or chemistry (Roberts et al. 1990,

15 Lessard-Pilon et al. 2010), while tubeworms tend to increase their dominance when

16 fluid flow declines and can persist for years (Bergquist et al. 2003a, b, Cordes et al.

17 2005b). Finally, Lessard-Pilon et al. (2010) attributed a 15 year succession pattern

18 between tubeworm and mussel populations to renewed or redirected active seepage.

19 During the West African Cold Seeps (WACS) cruise in February 2011, the Regab

20 pockmark was intensively surveyed and a 14,000 $\mathrm{m}^{2}$-large video-mosaic was

21 assembled to map the main populated area of the pockmark. A subset of this same

22 area had already been described by Olu-Le Roy et al. (2007a), who provided a

23 detailed description of the spatial patterns of the faunal assemblages, highlighting

24 high degree of spatial heterogeneity. This work was based on imagery data, and in

25 particular on video-mosaics, taken in 2001 during the Biozaire cruise. 
1 Using geo-referenced mosaics and geographic information systems (GIS), we provide

2 a description of the current distribution of the dominant megafauna (mussels,

3 tubeworms, clams) and its ten-year development in one of the most densely populated

4 areas of the Regab pockmark. We identify vestimentiferan tubeworms, bathymodiolid

5 mussels and vesicomyids that create the dominant habitats of the pockmark. To our

6 knowledge this is the first study of the temporal variation of the distribution of 7 chemosynthetic fauna at this scale and including such diverse habitats.

\section{2. Site description}

10 The Regab pockmark is located on the passive Congo-Angola margin at $3160 \mathrm{~m}$ water

11 depth, about $10 \mathrm{~km}$ to the north of the Congo deep-sea canyon. The pockmark is a

12 circular-shaped depression on the seafloor that is less than $20 \mathrm{~m}$ deep and about $800 \mathrm{~m}$

13 wide (Charlou et al. 2004, Ondréas et al. 2005) (Figure 1). Regab has been described

14 as a 'pockmark cluster' since it is considered to be composed of several smaller

15 pockmarks (Ondréas et al. 2005). These features are believed to result from seafloor

16 collapses following the release of over-pressured interstitial fluids. This was

17 suggested after seismic profiles showed the presence of a 300 m-deep subsurface pipe

18 rooted in a palaeo-channel that acts as a reservoir for the accumulating fluids

19 (Ondréas et al. 2005, Gay et al. 2006). Trapped fluids are mostly enriched in methane

20 and are believed to be produced in deeper layers of sediment by microbial activity

21 (Charlou et al. 2004). The presence of gas hydrates was observed both in hydrate

22 outcrops at the sediment surface and in gravity cores down to a depth of $6 \mathrm{~m}$ (Charlou 23 et al. 2004, Ondréas et al. 2005). Sulfide is produced from methane and sea-water

24 sulfate in the subsurface sediment by anaerobic methane oxidation, which has been

25 identified in the different habitats (Cambon-Bonavita et al. 2009). 
1 The most active area in terms of fluid escape is a $600 \mathrm{~m}$-long and $200 \mathrm{~m}$-wide $\mathrm{N} 70^{\circ}$ -

2 directed area located near the middle of the pockmark. This area corresponds to a

3 zone of extensive carbonate crusts and it seems to host most of the fauna that have

4 been identified at the pockmark (Ondréas et al. 2005). The faunal communities

5 present at Regab are dominated by symbiont-bearing species including

6 vestimentiferan tubeworms of the species Escarpia southwardae (Andersen et al.

7 2004), two species of Vesicomyidae bivalves, Laubiericoncha chuni and

8 Christineconcha regab (Cosel \& Olu 2008, 2009, Krylova \& Cosel 2011), and one

9 species of the mussel Bathymodiolus aff. boomerang (Olu-Le Roy et al. 2007b).

10 These foundation species create habitats that support associated heterotrophic macro-

11 and meio-faunal communities which vary in biomass and diversity among habitats

12 (Gaever et al. 2009, Menot et al. 2009, Olu et al. 2009).

\section{3. Methods}

\section{$15 \quad 3.1 \quad$ WACS mosaic}

\section{$16 \quad 3.1 .1 \quad$ Acquisition}

17 Imagery used for the production of mosaics was acquired with a high-definition color

18 video camera over two ROV dives during the WACS cruise with RV Pourquoi Pas?.

19 The camera is mounted vertically on the ROV Victor 6000 and is dedicated to high-

20 resolution mosaicking applications. The surveys were carried out in a structured way

21 by performing parallel line surveys separated by 3 -meter intervals, from an average

22 altitude of 3 meters, so as to ensure overlap between the mosaic lines. The total

23 surveyed area covers a rectangular surface of about $65 \times 220 \mathrm{~m}^{2}$ (Figure 2). The limits

24 of this surface correspond to the limits of the 'mosaic 2' produced by Olu-Le Roy et al. 
1 (2007a) from images acquired during the BIOZAIRE cruise in 2001. The reason for

2 this is to enable later comparison of the two mosaics. To minimize drift-induced

3 positioning errors, the survey area was split into two equal subareas of $65 \times 115 \mathrm{~m}^{2}$

4 each (Figure 2). The survey required a total of twenty-one lines per subarea to cover

5 the entire surface. Each line was $115 \mathrm{~m}$ long in order to ensure overlap between the

6 two subareas. Moreover, the ROV position was regularly reset onto markers at the

7 beginning of lines in order to eliminate any drifting error before starting a new line.

8 During the survey, the maximum observed drift error at the end of a line was about 3

9 meters. The markers were also used to reset the ROV position when resuming the

10 survey in the second mosaicking dive. Final navigation is therefore a hybrid

11 navigation from USBL and dead-reckoning navigation reset with markers.

$12 \quad 3.1 .2$ Construction of the video-mosaic

13 The lines of mosaic were constructed using the Ifremer in-house MATISSE program

14 (Vincent et al. 2003, Allais et al. 2004). The MATISSE program was first designed for

15 online-videomosaicking, i.e. to build the mosaic while the survey is ongoing.

16 However, due to compatibility issues between the program and the new camera and

17 navigation systems of the ROV Victor 6000 , building the mosaic involved numerous

18 intermediate data manipulation steps and could not be performed in real-time. For

19 instance, the HD-formatted video files (1920x1080 pixels) had to be converted into

20 DVD-PAL format (720x576 pixels) before they could be read by MATISSE. This

21 involved adding black bands on the video files in order to preserve the 16/9-ratio of

22 HD frames. Conversion to DVD format was done with the ConvertXtoDVD

23 commercial program. Navigation files also had to be rewritten according to an older

24 standard to ensure compatibility with MATISSE. The navigation was then replayed

25 with the Ifremer TRIADE Software, a program that sends navigation entries to 
1 MATISSE at a real-time frequency in order to simulate an online mode. Mosaic lines

2 were then constructed at a real-time pace.

3 Each line of mosaic was constructed separately instead of letting Matisse run straight

4 from the beginning to the end of the survey. The reason was to keep size of files

5 small, and to allow more flexibility in the construction of the final areal mosaic.

$6 \quad 3.1 .3 \quad$ GIS and spatial analyses

7 The separate lines were imported and geo-referenced into ArcGIS. Geo-referencing

8 was done with the ROV navigation data, but caution was taken that corresponding

9 features between overlapping segments match on the same points.

10 For all mosaics, surficial features were manually delineated and polygons were

11 created in ArcGIS to map the spatial distribution of each feature. Mapped features are

12 similar to those used for the Biozaire mosaic (Olu-Le Roy et al. 2007a), and the main

13 categories are: dense Mytilidae, sparse Mytilidae, dead Mytilidae, Escarpia-Mytilidae

14 co-occurrence, dense E. southwardae, sparse E. southwardae, juvenile $E$.

15 southwardae, recumbent E. southwardae, senescent E. southwardae, living

16 Vesicomyidae, mixed (living and dead) Vesicomyidae, dead Vesicomyidae, carbonate

17 concretions (Figure 3). Areas of coverage were computed for each non-sparse

18 category in ArcGIS, using the Mollweide equal-area projection.

19 The dense Mytilidae category refers to areas where the living mussel distribution is

20 almost continuous and where the substratum is rarely visible. Conversely, sparse

21 Mytilidae applies to areas where the substratum is clearly visible between the

22 individuals. Such distinction was not made for the dead Mytilidae category. The dense

23 E. southwardae category refers both to single large bushes of adult tubeworms, and to

24 fields of bushes of adult tubeworms, whereas the sparse E. southwardae category 
1 corresponds to areas where bushes of adult tubeworms are not closely distributed and

2 contain relatively few tubes (roughly 10 or less). The juvenile E. southwardae

3 category refers to bushes where tubeworms are of strikingly small size in comparison

4 to the adult community. The recumbent E. southwardae category designates bushes

5 where tubes are disposed horizontally, and the senescent category refers to dead

6 individuals and individuals in poor condition whose tubes lie on the seafloor. Patches

7 of vesicomyid clams are categorized either as living, mixed (dead and living) or dead.

8 Living clams are normally half buried and stand upright in the sediments, whereas

9 dead clam shells are generally open and lying in the sediments. The 'mixed' category

10 refers to patches that contain both living and dead clams. Carbonate crusts were

11 mapped only where concretions could clearly be seen on the images, and the mapped

12 areas often do not include the carbonated crusts that underlie the tubeworm

13 population, the dense mussel beds, or thin sediment covers.

14 The delineation process was supported by the use of the full HD resolution video files,

15 particularly for differentiating clams from mussels and living bivalves from dead

16 bivalves. Vesicomyid clams comprehend two species, Laubiericoncha chuni and

17 Christineconcha regab, that cannot be separated based on the images. However, both

18 in 2001 and in 2011, Christineconcha regab was largely dominant in samples and on

19 close-up views (Cosel \& Olu 2009, Decker et al. 2012).

\section{$21 \quad 3.2 \quad$ BIOZAIRE mosaic}

22 The BIOZAIRE mosaic corresponds to the 'mosaic 2' described in the literature (Olu-

23 Le Roy et al. 2007a). Due to the absence of navigation data, the BIOZAIRE mosaic

24 was never geo-referenced. But surfaces could be calculated anyway from the altitude 
1 of survey and the camera parameters. In this work we used the new WACS mosaic to

2 geo-reference each individual segment (76 segments) of the BIOZAIRE mosaic, with

3 an average root-mean-square (RMS) error of $0.03 \mathrm{~m}(\mathrm{SD}=0.1 \mathrm{~m})$ and a maximum

4 RMS error of $0.4 \mathrm{~m}$. The geo-referencing was done in ArcGIS by registering features

5 common to both mosaics, such as unchanged carbonate concretions, patches of dead

6 shells, detritus and also bushes of tubeworms. The advantage of this technique is that

7 it reduces the discrepancies between both mosaics, no matter how accurate the geo-

8 referencing of the WACS mosaic is. In other words, the same polygon should have the

9 same surface on both mosaics and patch sizes should be directly comparable, with a

10 low relative error. However, differences in angles of perspective, in image quality, in

11 visibility and in precision of delineation process also occur and cause some

12 discrepancies in the computed areas. Digitized polygons for living and dead mussel

13 patches are the most affected by such discrepancies.

14 In order to keep consistency with the published work, BIOZAIRE polygons were not

15 redrawn. Instead, the original polygons, drawn in Photoshop by Olu-Le Roy et al.

16 (2007a), were reused. This implied exporting every polygon layer from Photoshop.

17 Polygons were then imported as polygon features into ArcGIS and geo-referenced

18 over the BIOZAIRE mosaic. The surface areas were recalculated according to the new

19 geo-referencing data.

20 Additionally, qualitative direct visual comparison of the two mosaics allowed for

21 identification of small-scale localized changes, which could not be observed from the

22 digitized polygons. 


\section{4. Results}

\section{$2 \quad 4.1 \quad$ WACS mosaic (2011)}

3 The surveyed zone almost fully covers a 14,000 $\mathrm{m}^{2}$-large rectangular area directed in

4 a southwest-to-northeast direction (Figure 1). Direct mapping of the main faunal

5 assemblages and visible carbonate concretion areas is available for the entire study

6 area (Figure 4a). It shows that the substratum is composed either of soft sediments or

7 of harder carbonate concretions and that the faunal distribution is spatially non-

8 uniform but instead is divided into areas of high and low fauna presence. Areas of

9 high fauna presence can in turn be categorized based on the dominant type of fauna

10 (Figure 4b).

11 Carbonate concretions were visible over a large portion of the survey area (Figure 4b).

12 The total measured extent exceeds $4400 \mathrm{~m}^{2}$. This is however a minimum estimation

13 since it does not include carbonate concretions that were not directly visible at the

14 surface, i.e. concretions covered by sediments or underlying fields of tubeworms and

15 mussels.

17 4.1.1 Areas of high fauna presence

18 Mussel distribution

19 The map of faunal distribution (Figure 4a) shows that large mussel beds were round-

20 shaped and always adjacent to the tubeworms fields. At the limit between the two

21 aggregations, a transition zone with co-occurrence of mussels and tubeworms was

22 often observed. In these transition zones mussels were present on the substratum

23 between the tubeworms but they were also attached onto the tubeworms themselves. 
1 The mosaic and video material from ROV dives also indicated that areas of mussel

2 occurrence tended to coincide with areas of hard substrata, i.e. of carbonate

3 concretions, either bare or with thin sediment cover. Indeed, very few mussels were

4 observed on soft sediment areas; however, because the substratum type cannot be

5 reliably identified from the images under all mussel aggregates, the proportion of

6 mussel aggregates that were located in soft sediments could not be quantified.

7 The dense mussel category within the study area covered a total area of $414 \mathrm{~m}^{2}$ (Table

8 1) and was mostly concentrated in two main (M2/M3, M1) and one minor (M4) areas

9 (Figure 4b).

10 The largest mussel area, known from the Biozaire mosaic as "M2/M3", stretched out

11 over $20 \mathrm{~m}$ and $26 \mathrm{~m}$ in the SW-NE and NW-SE directions respectively; it had an

12 approximate surface of $450 \mathrm{~m}^{2}$, of which at least $300 \mathrm{~m}^{2}$ were covered by dense

13 mussels. Observations of video footages showed that a large part of the dense

14 population in this area was located at the bottom of a depression between boulders of

15 carbonate concretions (Figure 4a). This mussel bed stretched out towards the north

16 boundary of the mosaic and likely extended further.

17 The second main mussel area ("M1") was located at about a hundred meters to the

18 southwest of the first one. It was composed of two beds of dense living mussels, one

19 of about $45 \mathrm{~m}^{2}$ and the other of about $30 \mathrm{~m}^{2}$. The population was almost entirely

20 surrounded by dense bushes of tubeworms but image material shows that mussels

21 were also present, although at a lower density. Patches of dead mussels seemed to be

22 larger at M1, whereas the abundance of living mussels was visibly lower than at $23 \mathrm{M} 2 / \mathrm{M} 3$.

24 Additionally a minor mussel patch was present at the northeastern limit of the mosaic. 
1 In this area, the densest mussel bed covered an area of less than $10 \mathrm{~m}^{2}$, but was likely

2 to extend over the limit of the mapped area. This area is referred to as "M4".

4 Tubeworm distribution

5 The majority of the tubeworm population within the area of study was concentrated in

6 dense bushes. Bushes of tubeworms were in some places isolated but occurred more

7 commonly in large and dense fields. In either case, living tubeworms seemed to occur

8 only on carbonate concretions and mostly around the main mussel areas. However, the

9 substratum under dense tubeworms was not always visible on the images, and it could

10 not be ascertained whether all living tubeworms in the area of study occurred on

11 carbonate concretions.

12 The largest field with high tubeworms density was up to $1400 \mathrm{~m}^{2}$ in area and was

13 located near the middle of the study area, west-northwest of M2/M3. This area was

14 more elevated than in the rest of the study area. This was due to the presence of

15 blocks of hard concretions that gave the relief a rugged surface. A relatively high

16 visible abundance of mussels was observed within the transition zone between mussel

17 and tubeworm populations. In this area the transition zone was up to $7 \mathrm{~m}$ wide.

18 The second largest field of tubeworms covered an area of about $600 \mathrm{~m}^{2}$ and

19 surrounded M1 almost entirely. In this field, the zone of co-occurrence between

20 tubeworms and mussels was very small and it was not observed all along the

21 mussel/tubeworm limit. The field stretched out farther towards the south-southwest

22 and beyond the limits of the study area.

23 The next largest fields of dense tubeworms were located at the eastern and

24 northeastern end of the mosaic. In this area, two fields of about $130 \mathrm{~m}^{2}$ each were 
1 separated by a zone of soft sediments and low fauna presence. A $55 \mathrm{~m}^{2}$-large zone of

2 co-occurrence between tubeworms and mussels could be observed in the vicinity of

3 M4.

4 Juvenile tubeworms were mostly observed as isolated bushes or as small fields in the

5 periphery of the large aggregations of dense tubeworms. Observed juveniles also

6 seemed to occur consistently on carbonate concretions, but generally close to or at the

7 limit between concretions and soft sediments (Figure 5). They were never observed

8 more than $3 \mathrm{~m}$ away from the limit of the concretions, and never on the most

9 protruding, and likely thicker, concretions. Mussels were also observed within

10 populations of juvenile tubeworms, where those bordered the mussel beds.

11 Senescent and/or recumbent populations were rarely observed, and never within the

12 main tubeworms aggregations. The main occurrences were located in the periphery of

13 larger fields of tubeworms. Additionally, senescent tubeworms were often located

14 over soft sediments (Table 1) and in the immediate vicinity of clam aggregations.

\section{Vesicomyid clam distribution}

17 Vesicomyids were observed in aggregates of very variable dimensions, and ranged

18 from very small clusters of about $0.01 \mathrm{~m}^{2}$ to large fields of up to $400 \mathrm{~m}^{2}$, gathering

19 living, dead or mixed (i.e. dead and living) individuals. However, most aggregates

20 contained mixed individuals, and it was hard to quantify the relative proportion of

21 living and dead individuals from the images. In a few cases, small clusters of living

22 clams could be observed and delineated within larger patches of mixed (dead and

23 living) clams. Dimension of individual aggregates of living clams in the survey area

24 did not exceed $3 \mathrm{~m}^{2}$. 
1 Clam communities seemed limited to the areas covered by soft sediments (Table 1).

2 For instance, clusters of living vesicomyids were scattered across the mosaic but were

3 almost consistently (273 out 276 clusters) observed in the areas covered with soft

4 sediments (Table 1). Furthermore, 241 out of 276 clusters of living vesicomyids were

5 located in patches of dark reduced sediments, which correspond to $94 \%$ of the total

6 area $\left(88 \mathrm{~m}^{2}\right)$ covered by clusters of living vesicomyids (Table 1). Generally, dead

7 vesicomyids were more commonly observed on carbonate concretions (13\%) than

8 living (2\%) and mixed (5\%) vesicomyids.

9 The vesicomyid population was very patchy and heterogeneously distributed within

10 soft sediment areas (Figure 4a); in particular, it concentrated mostly at the periphery

11 of the main mussel/tubeworm aggregations (Figure 4b). The largest field of

12 vesicomyids occurred in the vicinity of M4; within this field, living and mixed (living

$13+$ dead) vesicomyids covered respectively $39 \mathrm{~m}^{2}$ and $258 \mathrm{~m}^{2}$.

\section{$15 \quad 4.1 .2$ Areas of low fauna presence}

16 Areas of low fauna presence exhibited strikingly low numbers of tubeworms, clams,

17 and mussels patches in comparison to the rest of the survey area (Figure 4a). Apart

18 from the highly mobile fauna such as the galatheids, most of the fauna in those areas

19 was composed mainly of sparse patches of tubeworms $\left(\leqslant 25 \mathrm{~m}^{2}\right)$ or of living and

20 mixed (dead and living) clams $\left(\leqslant 20 \mathrm{~m}^{2}\right.$ ). Dead clam shells were also frequently

21 observed.

22 The least-colonized zone was located to the south of the large mussels and tubeworms

23 communities located in the middle of the survey area. It covered an area of about

$241000 \mathrm{~m}^{2}$ and was mostly composed of soft, bioturbated sediments. 
24.2 Comparison with BIOZAIRE mosaic (2001)

3 The Biozaire mosaic (2001) does not provide contiguous areal coverage such as the

4 WACS mosaic (2011), and large gaps occur between individual lines. Both mosaics

5 overlap over a $4605 \mathrm{~m}^{2}$-large area, which correspond to a subset only of the WACS

6 mosaic area. In order to compare the trend in faunal distribution, this overlapping area

7 is shown for the Biozaire and WACS videomosaics (Figure 6). Overall, there were

8 only little changes in the spatial location of the main faunal assemblages.

9 The mussel distribution has remained mostly the same as it was during the Biozaire

10 cruise. Although it is hard to compare the size of the main aggregations due to the

11 smaller coverage of the Biozaire mosaic, there is evidence that M2/M3 contained a

12 larger mussel population on the WACS mosaic than on the Biozaire map, with fewer

13 gaps between the different patches (Figure 7a). Conversely, some small mussel beds at

14 M1 seem to have disappeared and to have been replaced by dead mussel shells

15 (Figure 7b). M4 is not covered by the Biozaire mosaic and cannot be compared.

16 Tubeworm fields showed no change in distribution, the slight difference in polygon

17 sizes being more due to the lower resolution of the Biozaire imagery data than on

18 actual distribution changes. From these results, the tubeworm community is believed

19 to be the one that changed the least across the study area. Most bushes or even single

20 tubeworms were found unchanged and in some cases in the exact same position than

21 in the older mosaic (Figures 7c, 8). Tubeworms were indeed the most reliable features

22 when geo-referencing the Biozaire mosaic onto the WACS mosaic.

23 The vesicomyid clam population is the fauna that changed the most since the Biozaire

24 cruise. Although the main clam fields have remained at the same locations, their sizes 
1 seem to have increased. In addition, at least 38 new patches of living clams were

2 observed that did not exist during the Biozaire cruise. Those new patches had a mean

3 size of $0.5 \mathrm{~m}^{2}\left(\mathrm{SD}=0.6 \mathrm{~m}^{2}\right)$, and their areas sum up to $17 \mathrm{~m}^{2}$. They were often

4 located in the close vicinity of older patches (Figure $8 \mathrm{~b}$ ), but were also in a few cases

5 new settlements farther from previously existing patches (Figure 8a). Conversely, 16

6 patches were identified on the Biozaire mosaic, which did not exist anymore in 2011

7 or at least, which were buried under some sediments (Figure 8c). They had a mean

8 size of $0.3 \mathrm{~m}^{2}\left(\mathrm{SD}=0.2 \mathrm{~m}^{2}\right)$, and cover a total area of $4.6 \mathrm{~m}^{2}$. About 4 of those 16

9 patches contained dead clams only.

10 Areas of coverage by dense mussels, tubeworms and clams were computed for both

11 the Biozaire and the WACS faunal distribution maps (Table 2). Areas of sparse mussel

12 and sparse tubeworm occurrence are not shown due to too large errors in delineating

13 sparse aggregations. In addition, to keep consistency with previous work on the

14 Biozaire mosaic, areas with co-occurrence of living mussel and tubeworm are given

15 (Table 2). Given a total common area of $4605 \mathrm{~m}^{2}$ between the Biozaire and the WACS

16 mosaics, areas can be expressed in percentage of cover of the overlap area. According

17 to these calculations, coverage changes were very low and remained below $2 \%$ of the

18 total overlap area for every category. Patches of living tubeworms, tubeworms with

19 mussels and mixed (dead and living) clams underwent the largest changes, with

20 coverage increases of up to $1.5,1.3$ and $1.2 \%$ of the total overlap area respectively

21 (Table 2). The total areal extent of the other assemblages showed almost no change.

22 Overall, the distribution of the carbonate concretions over the study area did not 23 change between the Biozaire and the WACS cruises. The higher resolution of the new

24 mosaic allowed better definition of the limits of the concretions, especially in areas

25 covered with tubeworms or mussels, and no major new area of occurrence was 
1 observed. On the contrary, in many places the carbonate concretions tended to slightly

2 disappear under a thin sediment cover.

\section{5. Discussion}

$5 \quad 5.1 \quad$ Faunal and carbonate distribution

6 The mosaic and the distribution map of the megafaunal communities give a very

7 detailed view and full coverage of the entire study area. The results show that the

8 megafauna at Regab is concentrated mainly in three distinct areas of high fauna

9 presence, separated by areas of relatively lower presence. Such distribution indicates

10 that the chemical fluxes that are required to sustain these chemosynthetic communities

11 are heterogeneous over the study area. Indeed, the distribution of the main faunal

12 assemblages showed a concentric spatial zonation pattern starting from mussel beds in

13 the middle to tubeworms and finally fields of vesicomyids towards the outside. In our

14 study this spatial zonation pattern from mussels to vesicomyid clams was observed, to

15 various extents, around the three main mussel areas (M1, M2/M3, M4).

16 A model presenting a concentric pattern has been proposed previously for the Regab

17 pockmark (Gay et al. 2006), but it considered both mussels and tubeworms as

18 methane-dependant species inhabiting the same carbonate-dominated facies (Olu-Le

19 Roy 2006). Although Bathymodiolus aff. boomerang contains both methanotrophic

20 and thiotrophic symbionts (Duperron et al. 2005) and, for the populations living in the

21 Regab pockmark, is known to rely on methane as dominant energy source (Olu et al.

22 2009, Duperron et al. 2011), tubeworms are known to host sulphur-oxydizing

23 symbionts (Dubilier et al. 2008) and to have very high demands in terms of sulfide

24 supply (Cordes et al. 2003). 
1 We postulate that the observed distribution is controlled by the strength of fluid

2 advection and related methane fluxes, and propose a model in which the megafaunal

3 distribution at Regab is structured by the presence of discrete zones of intense fluid

4 advection and methane fluxes under the mussel beds (Figure 9). The distribution of

5 the other communities would therefore be related to decreasing advection rates with

6 distance from the mussel beds. The existence of such localized pathways of high fluid

7 advection rate is compatible with the current understanding that the center of the

8 pockmark is composed of several smaller pockmarks (Ondréas et al. 2005). In this

9 section we discuss the concepts of this model, and confront them to more detailed

10 observations of the faunal distribution and of the presence/absence of carbonate

11 crusts.

12 Our observations show that the main mussel beds occur in areas where carbonates

13 form blocs of indurated sediments and concretions within slight depressions, and that

14 the main tubeworm aggregations occur in areas with extensive, continuous and

15 prominent carbonate crusts. The formation of authigenic carbonates is a byproduct of

16 the anaerobic oxidation of methane (AOM) in the sediment (Boetius et al. 2000,

17 Aloisi et al. 2002) and is an indicator of methane fluxes and microbial activity within

18 the sediments. However, the formation of continuous carbonate crusts impacts the

19 porosity and permeability of the sediments and hence reduces the possible pathways

20 for methane- and sulfide-rich fluid escapes and for sulfate-rich seawater infiltration

21 (Hovland 2002, Luff et al. 2004). Therefore, areas of mussel occurrence are likely to

22 be characterized by higher fluxes between the sediments and the bottom water than

23 the encrusted areas where tubeworms occur.

24 We propose that the three main mussel areas present in our study area are located on

25 focused zones where the seepage activity is the strongest, and where fluid flow is 
1 intense enough for the methane fluxes to reach the sediment/water interface. Indeed,

2 the distribution of mussels mainly in dense circular beds suggests the presence of

3 localized areas of intense methane fluxes. This hypothesis was mentioned previously

4 from the results of the Biozaire mosaic (Ondréas et al. 2005, Olu-Le Roy et al.

5 2007a). It also is strongly supported by recent biogeochemical analyses in various

6 Regab habitats, according to which extensive seepage of gaseous and dissolved

7 methane was observed only under the mussel habitat (Pop Ristova et al. 2012). This is

8 also in accordance with previous studies in other areas that showed that release of

9 methane to the water column is indeed facilitated in areas of high flux (Boetius \&

10 Suess 2004, de Beer et al. 2006, Niemann et al. 2006).

11 Co-occurrence of mussels and tubeworms is commonly observed at the transition

12 between the two populations. In such zones, numerous mussels are observed onto the

13 tubes of the vestimentiferan aggregations that directly border the mussel beds. This

14 could be the result of space limitations within the mussel beds, which would constrain

15 mussels to invade neighboring tubeworm aggregations. Indeed, the dual symbiosis of

16 B. aff. boomerang allows this species to use both methane and sulfide, similarly to

17 several other seep and vent mussels of the Bathymodiolus genus (Duperron et al.

18 2005). However, unlike in the gills of Bathymodiolus azoricus at Mid-Atlantic

19 hydrothermal vents, symbionts in seep mussel gills at Regab and at Gulf of Mexico

20 seeps are predominantly methanotrophic; the thiotrophic symbionts are likely limited

21 by the absence or low level of sulfide in the seawater (Duperron et al. 2011).

22 Moreover, the fact that mussel/tubeworm co-occurrence zones are mostly close to the

23 main mussel beds may also support the hypothesis that methane fluxes are higher in

24 those areas than in the tubeworms aggregations located farther from the mussel beds.

25 This is in accordance with previous studies, which indicate that mussel beds at Regab 
1 are located in areas with the highest concentrations of methane in the water (Charlou

2 et al. 2004, Olu-Le Roy et al. 2007a). Such behavior was also observed for

3 methanotrophic mussel populations in the Southern Barbados prism (Olu et al. 1996b)

4 and along the Costa Rica margin (Mau et al. 2006). In the Gulf of Mexico, mussels

5 associated to brine seeps with high methane concentration grow faster and are in

6 better physiological condition than those from petroleum sites with low methane but

7 high sulfide concentrations (Bergquist et al. 2004).

8 The distribution of the tubeworms aggregations around the mussel beds could reflect

9 lower fluid advection rates than under mussel beds. Niemann et al. (2006) and de Beer

10 et al. (2006) suggested that by preventing downward fluxes of sulfate-rich water into

11 the sediments, intense fluid advection rates can hinder the efficiency of AOM. This is

12 in accordance with results from Pop Ristova et al. (2012), who calculated the

13 proportion of upward diffusing methane that is removed by AOM at Regab to be only

$146-20 \%$ under a mussel habitat compared to $47-97 \%$ in lower flux areas such as under

15 clam habitats. Such processes could result in different environmental conditions inside

16 and outside the mussel beds, and partly control the relative distribution of tubeworms

17 and mussels. Biotic interactions are known to occur between mussels and tubeworms

18 at hydrothermal vents (Johnson et al. 1994, Desbruyères 1998, Lenihan et al. 2008).

19 For instance, mussels of the species Bathymodiolus thermophilus are able to disperse

20 fluids laterally (Johnson et al. 1994), which could make fluids unavailable for

21 tubeworms, and to inhibit recruitment of other vent species (Lenihan et al. 2008).

22 Such interactions could also apply in dense $B$. aff. boomerang aggregations. However,

23 unlike vent tubeworms, which take up sulfide from the seawater (Arp et al. 1985),

24 seep tubeworms such as E. southwardae take up sulfide directly from the sediments

25 through their roots (Julian et al. 1999, Andersen et al. 2004), and are likely unaffected 
1 by fluid dispersion by the mussels. Furthermore, sulfide is almost absent of the

2 seawater overlying mussel beds at Regab (Olu-Le Roy et al. 2007a, Duperron et al.

3 2011). Therefore, the absence of tubeworms in mussel beds is more likely due to

4 competition for space or to reduced AOM efficiency rather than biotic interactions.

5 Our observations show that large tubeworm aggregations around the main mussel

6 beds correspond to areas where the carbonate crusts are most prominent, and likely

7 the thickest. Carbonate precipitation likely reduced methane flux, thus enhancing

$8 \mathrm{AOM}$ and sulfide production, and favoring tubeworm settlement and dominance over

9 mussels. Moreover, as observed at Gulf of Mexico seeps, tubeworms of the species

10 Lamellibrachia luymesi were shown to release sulfate through their roots into the

11 sediments (Cordes et al. 2005a), thus preventing a potential sulfate-depletion of the

12 sediments. This characteristic is believed to allow adult L. luymesi to fuel or even

13 enhance the AOM (Cordes et al. 2005a, Dattagupta et al. 2008) in order to maintain

14 their supply in sulfide. As a result, the vestimentiferan population contributes to the

15 formation of carbonates, which is supported by our observations that tubeworms are

16 present where concretions form continuous and prominent crusts.

17 Juvenile tubeworms consistently occur near or at the limit between carbonate crusts

18 and bare sediments. Sulfide fluxes and concentrations are likely to be higher in such

19 areas with unsealed sediment/water interface than in areas covered by thick crusts,

20 and thus to provide a suitable environment for the larvae to settle until they can self-

21 maintain their supply of sulfide. According to Bergquist et al. (2002), the recruitment

22 of new tubeworms of the species Lamellibrachia luymesi and Seepiophila jonesi is

23 time-constrained and stops in older aggregations, due to the presence of thick

24 carbonate pavements and low concentrations of sulfide in the water (Bergquist et al.

25 2003a). Sulfide concentrations have indeed been reported to be higher around 
1 aggregations of juvenile than within older aggregations (Bergquist et al. 2003b).

2 This interpretation is further supported by the occurrence of bands of black reduced

3 sediments along the limits of the vestimentiferan-hosting carbonate concretions

4 (Figure 5), indicating that AOM and sulfide release occur in those areas. These

5 features also suggest that part of the methane fluxes trapped beneath the carbonates

6 could be redirected toward the sides of the carbonate crusts.

7 The distribution of the vesicomyid population is likely related to even lower advection

8 rates than the tubeworm aggregations. Vesicomyid clams require soft substrata to

9 access sulfide through their foot and, thus, are generally excluded from encrusted

10 areas. Results show indeed that the living vesicomyid clams are mainly located in the

11 soft sediment areas surrounding the tubeworms and mussel aggregations. However,

12 according to our interpretation, those areas are also where methane and sulfide fluxes

13 are lower. In particular, Olu-Le Roy et al. (2007a) observed that vesicomyid clams at

14 Regab are located in areas with relatively low methane concentrations, in comparison

15 to tubeworm and mussel habitats. This is consistent with the current understanding

16 that methane/sulfide availability shapes the structure of the microbial and megafaunal

17 communities (Olu et al. 1996a, b, 1997, Sahling et al. 2002, Sibuet \& Olu-Le Roy

18 2002, Levin et al. 2003, Levin 2005, Ritt et al. 2011, Pop Ristova et al. 2012).

19 The vesicomyid clam environment is sometimes proposed as being a precursor stage

20 towards a tubeworms/carbonate environment (Sahling et al. 2008). This is partly

21 supported by our observations of dead shells occurrences on some bare carbonate

22 concretions. Also, the presence of dead shells within the concretions has been reported

23 previously (Pierre \& Fouquet 2007). These observations suggest that areas with

24 vesicomyids transfer to the formation of carbonated crusts, either with or without

25 vestimentiferans. However, we have also observed large patches of dead vesicomyid 
1 shells within the sediments, sometimes almost buried, that would suggest that seepage

2 activity in these areas decreased or stopped and that living populations either died or

3 moved away. Such areas might never turn into tubeworms/carbonate environments

4 due to too low or too transient fluxes. Thus, vesicomyid populations might not be

5 restricted to one particular successional stage of colonization, but be present in a

6 range of areas representing different development stages of the seeping activity and

7 the observed patterns of distribution reflect the spatial heterogeneity of fluid flux.

8 Bergquist et al. (2003b) and Cordes et al. (2005b) suggested that the relative

9 distribution of mussels (Bathymodiolus childressi) and tubeworms (L. luymesi and $S$.

10 jonesi) could be related to different stages of succession, and explain that mussel beds

11 indicate an earlier stage of colonization that would later be replaced by tubeworms,

12 when the formation of carbonate concretions reduces the methane supply to the water

13 column.

14 However, we propose that the situation at Regab is more complex, as the observed

15 patterns of fauna distribution could also be partly related to spatial heterogeneity of

16 the fluid advection regime. Indeed, the particularity of this site is the coalescence of

17 several pockmarks within the Regab site that may differ by their fluid flow regime or

18 their evolution stage (Ondreas et al. 2005; Gay et al. 2006). If the relative

19 mussel/tubeworm distribution was solely related to different colonization stages, the

20 mussel population would expectedly be observed mainly together with, or in the

21 vicinity of, juvenile tubeworm aggregations. Although we do observe juveniles

22 around some small mussel clusters, the larger mussel beds present in the study area

23 are predominantly bordered by large adult tubeworm aggregations. Considering the

24 extreme slow growth rate of tubeworms (Fisher et al. 1997, Bergquist et al. 2000), this

25 indicates that fluid advection in those areas has been going on for a relatively long 
1 time, but that recruitment of juvenile has not occurred or has been hindered.

\section{$3 \quad 5.2 \quad$ Temporal comparison}

4 The comparison of the maps of faunal distribution and of the computed areas reveals

5 that the size of the areas of faunal occurrence has remained globally the same between

6 the Biozaire (2001) and the WACS (2011) cruises. We consider the discrepancies in

7 computed values and mapped areas to be largely caused by uncertainties in the

8 method. First, images for each mosaic have been taken with different camera and

9 lighting setups, which results in different resolutions and visibilities between the

10 Biozaire and WACS mosaics. Furthermore, small perspective distortions can, in

11 places, impact the precision of the relative geo-referencing of the mosaics, or make a

12 same feature look larger on one mosaic than on the other. Finally, the delineation

13 process is a manual step that highly depends on the interpretation and precision of the

14 observer. For all these reasons, mapped features may look different and discrepancies

15 in the computed areas may arise that are difficult to evaluate. Nevertheless,

16 considering all these possible sources of uncertainty and the large size of the study

17 area, the computed areas are remarkably consistent between the two mosaics. Indeed,

18 quantitative results showed that the changes in coverage per category are lower than

$192 \%$ of the overlap area, which suggest very little change between the two mosaics.

20 However, based on qualitative observations described below, we consider that the

21 calculated areas are impacted by errors of the method and cannot be used to analyze

22 further such small variations in the areas of faunal cover.

23 For instance, our observations of the mosaics confirm that no change occurred in the

24 population of tubeworms within the overlap area over the past 10 years. Indeed, an 
1 increase of the area covered by tubeworms would signify that recruitment occurred.

2 However, we did not observe new juvenile aggregations, possibly because the

3 observation period was too short and that juveniles are still too small to be seen, or

4 that the recruitment in the area covered by the mosaics was somehow limited. Overall,

5 the absence of changes in the vestimentiferan population is in accordance with the

6 findings that some tubeworms (L. luymesi and $S$. jonesi) may be very slow-growing

7 and long-living (Fisher et al. 1997, Bergquist et al. 2000). Nevertheless, Lessard-Pilon

8 et al. (2010) did observe evidences of tubeworm recruitment (Lamellibrachia spp. or

9 Escarpia laminata) within discrete seep communities in the Gulf of Mexico after a 15

10 year period, thus confirming that changes within tubeworms communities could be

11 observed on such time-scales. Their work was based on a comparatively small study

12 area $\left(23.4 \mathrm{~m}^{2}\right)$ and observations were likely more detailed than in our study (4605

$13 \mathrm{~m}^{2}$ ); indeed, they used photo datasets, which provided higher definition images and

14 closer views of the seafloor. Hence, tubeworm recruitment may have occurred within

15 our study area, but it is not evident from our data.

16 Conversely, some changes in size of individual beds of living and dead mussels were

17 observed, which suggest that localized variations of methane fluxes or carbonate

18 precipitation may have occurred. For instance, small scale visual observations suggest

19 that the dense mussel bed in M2/M3 could contain, in the overlap area, a greater

20 abundance of mussels in 2011 than in 2001, and that some minor mussel beds at M1

21 disappeared. This could indicate that the intensity of fluxes increased in M2/M3 and

22 decreased in M1. A decrease in activity in M1 would be consistent with the findings

23 of Olu-Le Roy et al. (2007a), who also hypothesized that a decreasing methane flux

24 occurs in this area, based on the lower density of the mussel beds. Alternatively, the

25 mussel abundance might have been stable and the observed changes could reflect a 
1 rearrangement of the mussels. In either case, distribution changes are likely the result

2 of local variations in environmental conditions.

3 However, the observed changes were localized and, overall, the mussel population

4 showed very little variation. Despite the scale difference between the two studies,

5 these findings are consistent with observations of Lessard-Pilon et al. (2010). Both

6 studies agree that only little change was observed on the total area covered by

7 foundation fauna. However, Lessard-Pilon et al. (2010) observed significant small-

8 scale changes in the distribution of mussel populations (Bathymodiolus brooksi and

9 Bathymodiolus heckerae), and reported that about $50 \%$ of the area originally covered

10 by living mussels at one site had been, after a period of 15 years, either replaced by

11 dead mussel shells or colonized by tubeworms (Lamellibrachia spp. or Escarpia

12 laminata). Interestingly, as we observed at Regab, the hydrothermal vent mussel

13 population of Bathymodiolus azoricus, was described to be stable on a decadal scale

14 in terms of overall percentage of colonization (Cuvelier et al. 2011), while small

15 fluctuations occurred on shorter time scales and on smaller spatial scales for seep

16 mussels of the Gulf of Mexico (Lessard-Pilon et al. 2010).

17 In our study, no change was observed in the tubeworm aggregations surrounding these

18 areas where mussel distribution varied. Mussel populations are expected to be more

19 dynamic and to respond faster to environmental changes than tubeworms (Lessard-

20 Pilon et al. 2010), which may be insensitive to small variations of seepage activity.

21 Alternatively, the increased dead mussels occurrence in M1 could reflect a late stage

22 of the successional model developed by Bergquist et al. (2003b), characterized by a

23 decrease of mussel population due to a decrease of methane and maybe of sulfide in

24 the water column. Indeed mussels are associated to areas of vigorous seepages and

25 high methane concentrations (Nix et al. 1995, Bergquist et al. 2005). However, the 
1 model proposed by Bergquist et al. (2003b) is true for long time-scales and it is

2 uncertain whether such trend is detectable within a 10 -year period.

3 Changes in the population of vesicomyid clams were more frequently observed than

4 for the mussel population. Although we cannot conclude if the total living population

5 globally did change, the location of the aggregates of living individuals shows

6 relatively more differences in comparison to the other populations studied. Indeed,

7 several patches of living individuals observed in the 2011 mosaic did not exist in

8 2001. Conversely some patches of vesicomyid clams that existed in 2001 did not exist

9 anymore in 2011. Also, in some cases, old patches of dead clams were re-colonized by

10 living clams. However, changes in the distribution of patches of living/dead clams are

11 difficult to apprehend since the relative proportion of living and dead clams cannot be

12 estimated from the images. Overall, the distribution of living vesicomyid clams is 13 very patchy and is difficult to understand.

14 Sahling et al. (2008) proposed a model for pockmarks of the Congo fan (100 km north

15 of Regab), in which the distribution of tubeworm (E. southwardae) and clam (of

16 similar species than at Regab) assemblages is controlled by the depth of the gas

17 hydrate deposits. The model considers that gas hydrates deposits act as "capacitors"

18 (Dickens 2003) that buffer the transient influxes of methane from below and that

19 ensure a more stable diffusion of methane into the pore water above, thus sustaining

20 long-living seep communities. We think that a similar control mechanism occurs at

21 Regab. Indeed, the presence of gas hydrates at Regab is known both from direct

22 observation of outcrops on the sediment surface and from sediment cores (Charlou et

23 al. 2004, Ondréas et al. 2005).

24 However, although this model is supported by the presence of such large populations 25 of long-living seep communities and by their spatial patterns of distribution, it does 
1 not fully explain the temporal changes observed within the clam populations. At

2 Regab, most aggregates of living individuals are indeed located within patches of

3 black sediments, indicating the occurrence of AOM; clams are mobile fauna, hence

4 changes in areas of distribution must somehow reflect changes of sulfide availability.

5 One possible explanation could be that gas hydrate deposits under clam communities

6 are either absent or too thin to buffer the transient methane fluxes over such a time

7 period. The observed changes in clam distribution would therefore be the response to

8 the transient release of methane and subsequent transient sulfide production. Clearly,

9 some monitoring of sulfide concentrations and some geological sampling under the

10 clam aggregates would be required to further refine this interpretation. However, this

11 is in accordance with other studies that suggest that vesicomyid clams are supported

12 by diffuse or transient fluxes (Olu et al. 1996a, b).

\section{6. Conclusion}

15 In this study, mosaic-based mapping of the faunal distribution over an area of 14,000

$16 \mathrm{~m}^{2}$ shows that the distribution of dominant megafaunal species (mussels, tubeworms,

17 clams) at Regab is mostly concentrated within three main megafaunal aggregations.

18 Within these three main aggregations, the faunal arrangement follows the same spatial

19 pattern with the methanotrophic mussels in the middle, then the vestimentiferans and

20 finally the vesicomyid clams on the outer zone. We interpret that each of these

21 patterns is centered on a zone of high flux of methane-enriched fluids. Such zones of

22 high fluid flow are responsible for the spatial variation of intensity of the fluxes

23 reaching the upper sediments and, hence, structure the distribution of the

24 chemosynthetic megafauna in the pockmark. 
1 In addition, this study is the first to describe the 10 -year variation of the megafauna

2 distribution in a cold seep environment over a $4600 \mathrm{~m}^{2}$-large area. Through

3 quantitative comparison of the two mosaics, it reveals that the overall size of the

4 dominant megafaunal populations of Regab did not change significantly $(<2 \%$ of the

5 comparison area), which indicates that the intensity of the methane and sulfide fluxes

6 that reach the faunal communities has been globally stable at the scale of the

7 comparison area. We interpret that such continuity could be related to the presence in

8 the sediments of gas hydrate deposits acting as "capacitors" for the methane fluxes.

9 Nevertheless, this study also shows that small-scale and discrete distribution changes

10 have occurred, as already observed at other seep and vent sites, but were too small to

11 be reliably quantified with our methodology. Those changes occurred mainly within

12 the living population of vesicomyid clams; this suggests that the clam community was

13 exposed to more transient fluxes than the mussel and tubeworm communities.

14 


\section{Acknowledgements}

2 We would like to thank the captain and the crew of RV Pourquoi Pas?, and the ROV

3 Victor 6000 team. Also thanks to Olivier Soubigou, Christophe Bayle and Michael

4 Aaron for their technical help and advices, and to James Collins for proofreading. We

5 are grateful to the entire team of the LEP for receiving me in their team.

6 This work was supported by the Ifremer and by the European Commission under the

7 EU Framework 7 funded Marie Curie Initial Training Network (ITN) SENSEnet 8 (contract $\left.\mathrm{n}^{\circ} 237868\right)$. 
References
Allais AG, Borgetto M, Opderbecke J, Pessel N, Rigaud V (2004) Seabed video mosaicking with MATISSE: a technical overview and cruise results. In: Proceedings of The Fourteenth International Offshore and Polar Engineering Conference. Toulon, France

Aloisi G, Bouloubassi I, Heijs SK, Pancost RD, Pierre C, Sinninghe Damsté JS, Gottschal JC, Forney LJ, Rouchy JM (2002) CH4-consuming microorganisms and the formation of carbonate crusts at cold seeps. Earth and Planetary Science Letters, 203, 195-203.

Andersen AC, Hourdez S, Marie B, Jollivet D, Lallier FH, Sibuet M (2004) Escarpia southwardae sp. nov., a new species of vestimentiferan tubeworm (Annelida, Siboglinidae) from West African cold seeps. Canadian Journal of Zoology, 82, 980-999.

Arp AJ, Childress JJ, Fisher CR (1985) Blood gas transport in Riftia pachyptila. In: Jones ML (ed) Hydrothermal vents of the Eastern Pacific: An overview. INFAX, Vienna, Va., p289-300.

Beer D de, Sauter E, Niemann H, Kaul N, Foucher JP, Witte U, Schlüter M, Boetius A (2006) In situ fluxes and zonation of microbial activity in surface sediments of the Håkon Mosby Mud Volcano. Limnology and Oceanography, 51, 13151331 .

Bergquist DC, Andras JP, McNelis T, Howlett S, Horn MJ Van, Fisher CR (2003a) Succession in Gulf of Mexico cold seep vestimentiferan aggregations: the importance of spatial variability. Marine Ecology, 24, 31-44.

Bergquist DC, Fleckenstein C, Knisel J, Begley B, MacDonald IR, Fisher CR (2005) Variations in seep mussel bed communities along physical and chemical environmental gradients. Marine Ecology Progress Series, 293, 99-108.

Bergquist DC, Fleckenstein C, Szalai EB, Knisel J, Fisher CR (2004) Environment drives physiological variability in the cold seep mussel Bathymodiolus childressi. Limnology and oceanography, 49, 706-715.

Bergquist DC, Urcuyo IA, Fisher CR (2002) Establishment and persistence of seep vestimentiferan aggregations on the upper Louisiana slope of the Gulf of Mexico. Marine Ecology Progress Series, 241, 89-98.

Bergquist DC, Ward T, Cordes EE, McNelis T, Howlett S, Kosoff R, Hourdez S, Carney R, Fisher CR (2003b) Community structure of vestimentiferangenerated habitat islands from Gulf of Mexico cold seeps. Journal of Experimental Marine Biology and Ecology, 289, 197-222.

Bergquist DC, Williams FM, Fisher CR (2000) Longevity record for deep-sea invertebrate. Nature, 403, 499-500.

Boetius A, Ravenschlag K, Schubert CJ, Rickert D, Widdel F, Gieseke A, Amann R, 
Jørgensen BB, Witte U, Pfannkuche O (2000) A marine microbial consortium apparently mediating anaerobic oxidation of methane. Nature, 407, 623-626.

Boetius A, Suess E (2004) Hydrate Ridge: a natural laboratory for the study of microbial life fueled by methane from near-surface gas hydrates. Chemical Geology, 205, 291-310.

Cambon-Bonavita MA, Nadalig T, Roussel E, Delage E, Duperron S, Caprais JC, Boetius A, Sibuet M (2009) Diversity and distribution of methane-oxidizing microbial communities associated with different faunal assemblages in a giant pockmark of the Gabon continental margin. Deep Sea Research Part II: Topical Studies in Oceanography, 56, 2248-2258.

Charlou JL, Donval JP, Fouquet Y, Ondréas H, Knoery J, Cochonat P, Levaché D, Poirier Y, Jean-Baptiste P, Fourré E, Chazallon B (2004) Physical and chemical characterization of gas hydrates and associated methane plumes in the Congo-Angola Basin. Chemical Geology, 205, 405-425.

Copley JTP, Jorgensen PB., Sohn RA (2007) Assessment of decadal-scale ecological change at a deep Mid-Atlantic hydrothermal vent and reproductive time-series in the shrimp Rimicaris exoculata. Journal of the Marine Biological Association of the United Kingdom, 87, 859-867.

Cordes EE, Arthur MA, Shea K, Arvidson RS, Fisher CR (2005a) Modeling the mutualistic interactions between tubeworms and microbial consortia. PLoS Biology, 3, 497-506.

Cordes EE, Bergquist DC, Shea K, Fisher CR (2003) Hydrogen sulphide demand of long-lived vestimentiferan tube worm aggregations modifies the chemical environment at deep-sea hydrocarbon seeps. Ecology Letters, 6, 212-219.

Cordes EE, Hourdez S, Predmore BL, Redding ML, Fisher CR (2005b) Succession of hydrocarbon seep communities associated with the long-lived foundation species Lamellibrachia luymesi. Marine Ecology Progress Series, 305, 17-29.

Cosel R von, Olu K (2008) A new genus and new species of Vesicomyidae (Mollusca, Bivalvia) from cold seeps on the Barbados accretionary prism, with comments on other species. Zoosystema, 30, 929-944.

Cosel R von, Olu K (2009) Large Vesicomyidae (Mollusca: Bivalvia) from cold seeps in the Gulf of Guinea off the coasts of Gabon, Congo and northern Angola. Deep Sea Research Part II: Topical Studies in Oceanography, 56, 2350-2379.

Cuvelier D, Sarrazin J, Colaço A, Copley JT, Glover AG, Tyler PA, Serrão Santos R, Desbruyères D (2011) Community dynamics over 14 years at the Eiffel Tower hydrothermal edifice on the Mid-Atlantic Ridge. Limnology and Oceanography, 56, 1624-1640.

Dattagupta S, Arthur MA, Fisher CR (2008) Modification of sediment geochemistry by the hydrocarbon seep tubeworm Lamellibrachia luymesi: A combined empirical and modeling approach. Geochimica et Cosmochimica Acta, 72, 2298-2315. 
Decker C, Caprais JC, Khripounoff A, Olu K (2012) First respiration estimates of cold-seep vesicomyid bivalves from in situ total oxygen uptake measurements. Comptes Rendus Biologies, 335, 261-270.

Desbruyères D (1998) Temporal variations in the vent communities on the East Pacific Rise and Galapagos Spreading Centre: a review of present knowledge. Cahiers de Biologie Marine, 39, 241-244.

Dickens GR (2003) Rethinking the global carbon cycle with a large, dynamic and microbially mediated gas hydrate capacitor. Earth and Planetary Science Letters, 213, 169-183.

Dubilier N, Bergin C, Lott C (2008) Symbiotic diversity in marine animals: the art of harnessing chemosynthesis. Nature Reviews Microbiology, 6, 725-740.

Duperron S, Guezi H, Gaudron SM, Pop Ristova P, Wenzhöfer F, Boetius A (2011) Relative abundances of methane- and sulphur-oxidising symbionts in the gills of a cold seep mussel and link to their potential energy sources. Geobiology, 9 , 481-491.

Duperron S, Nadalig T, Caprais JC, Sibuet M, Fiala-Medioni A, Amann R, Dubilier N (2005) Dual symbiosis in a Bathymodiolus sp. mussel from a methane seep on the Gabon continental margin (Southeast Atlantic): 16S rRNA phylogeny and distribution of the symbionts in gills. Applied and Environmental Microbiology, 71, 1694-1700.

Fisher CR, Urcuyo IA, Simpkins MA, Nix E (1997) Life in the slow lane: Growth and longevity of cold-seep vestimentiferans. Marine Ecology, 18, 83-94.

Gaever S van, Galéron J, Sibuet M, Vanreusel A (2009) Deep-sea habitat heterogeneity influence on meiofaunal communities in the Gulf of Guinea. Deep Sea Research Part II: Topical Studies in Oceanography, 56, 2259-2269.

Gay A, Lopez M, Ondréas H, Charlou JL, Sermondadaz G, Cochonat P (2006) Seafloor facies related to upward methane flux within a Giant Pockmark of the Lower Congo Basin. Marine Geology, 226, 81-95.

Hessler RR, Smithey WM, Boudrias MA, Keller CH, Lutz RA, Childress JJ (1988) Temporal change in megafauna at the Rose Garden hydrothermal vent (Galapagos Rift; eastern tropical Pacific). Deep Sea Research Part A Oceanographic Research Papers, 35, 1681-1709.

Hovland M (2002) On the self-sealing nature of marine seeps. Continental Shelf Research, 22, 2387-2394.

Jerosch K, Schlüter M, Foucher JP, Allais AG, Klages M, Edy C (2007) Spatial distribution of mud flows, chemoautotrophic communities, and biogeochemical habitats at Håkon Mosby Mud Volcano. Marine Geology, 243, $1-17$.

Johnson KS, Childress JJ, Beehler CL, Sakamoto CM (1994) Biogeochemistry of hydrothermal vent mussel communities: the deep-sea analogue to the intertidal 
zone. Deep Sea Research Part I: Oceanographic Research Papers, 41, 9931011.

Julian D, Gaill F, Wood E, Arp AJ, Fisher CR (1999) Roots as a site of hydrogen sulfide uptake in the hydrocarbon seep vestimentiferan Lamellibrachia sp. Journal of Experimental Biology, 202, 2245-2257.

Krylova EM, Cosel R von (2011) A new genus of large Vesicomyidae (Mollusca, Bivalvia, Vesicomyidae, Pliocardiinae) from the Congo margin, with the first record of the subfamily Pliocardiinae in the Bay of Biscay (northeastern Atlantic). Zoosystema, 33, 83-99.

Lenihan HS, Mills SW, Mullineaux LS, Peterson CH, Fisher CR, Micheli F (2008) Biotic interactions at hydrothermal vents: Recruitment inhibition by the mussel Bathymodiolus thermophilus. Deep Sea Research Part I: Oceanographic Research Papers, 55, 1707-1717.

Lessard-Pilon SA, Porter MD, Cordes EE, MacDonald IR, Fisher CR (2010) Community composition and temporal change at deep Gulf of Mexico cold seeps. Deep Sea Research Part II: Topical Studies in Oceanography, 57, 1891-1903.

Levin LA (2005) Ecology of cold seep sediments : Interactions of fauna with flow, chemistry and microbes. Oceanography and Marine Biology, 43, 1-46.

Levin LA, Ziebis W, Mendoza GF, Growney VA, Tryon MD, Brown KM, Mahn C, Gieskes JM, Rathburn AE (2003) Spatial heterogeneity of macrofauna at northern California methane seeps: influence of sulfide concentration and fluid flow. Marine Ecology Progress Series, 265, 123-139.

Luff R, Wallmann K, Aloisi G (2004) Numerical modeling of carbonate crust formation at cold vent sites: significance for fluid and methane budgets and chemosynthetic biological communities. Earth and Planetary Science Letters, 221, 337-353.

MacDonald IR, Sager WW, Peccini MB (2003) Gas hydrate and chemosynthetic biota in mounded bathymetry at mid-slope hydrocarbon seeps: Northern Gulf of Mexico. Marine Geology, 198, 133-158.

Mau S, Sahling H, Rehder G, Suess E, Linke P, Soeding E (2006) Estimates of methane output from mud extrusions at the erosive convergent margin off Costa Rica. Marine Geology, 225, 129-144.

Menot L, Crassous P, Desbruyères D, Galéron J, Khripounoff A, Sibuet M (2009) Colonization patterns along the equatorial West African margin: Implications for functioning and diversity maintenance of bathyal and abyssal communities. Deep Sea Research Part II: Topical Studies in Oceanography, 56, 2313-2325.

Mullineaux LS, Fisher CR, Peterson CH, Schaeffer SW (2000) Tubeworm succession at hydrothermal vents: use of biogenic cues to reduce habitat selection error? Oecologia, 123, 275-284. 
Niemann H, Lösekann T, Beer D de, Elvert M, Nadalig T, Knittel K, Amann R, Sauter EJ, Schlüter M, Klages M, Foucher JP, Boetius A (2006) Novel microbial communities of the Haakon Mosby Mud Volcano and their role as a methane sink. Nature, 443, 854-858.

Nix ER, Fisher CR, Vodenichar J, Scott KM (1995) Physiological ecology of a mussel with methanotrophic endosymbionts at three hydrocarbon seep sites in the Gulf of Mexico. Marine Biology, 122, 605-617.

Olu K, Caprais JC, Galéron J, Causse R, Cosel R von, Budzinski H, Ménach KL, Roux CL, Levaché D, Khripounoff A, Sibuet M (2009) Influence of seep emission on the non-symbiont-bearing fauna and vagrant species at an active giant pockmark in the Gulf of Guinea (Congo-Angola margin). Deep Sea Research Part II: Topical Studies in Oceanography, 56, 2380-2393.

Olu K, Duperret A, Sibuet M, Foucher JP, Fiala-Médioni A (1996a) Structure and distribution of cold seep communities along the Peruvian active margin: relationship to geological and fluid patterns. Marine Ecology Progress Series, 132, 109-125.

Olu K, Lance S, Sibuet M, Henry P, Fiala-Médioni A, Dinet A (1997) Cold seep communities as indicators of fluid expulsion patterns through mud volcanoes seaward of the Barbados accretionary prism. Deep Sea Research Part I: Oceanographic Research Papers, 44, 811-841.

Olu K, Sibuet M, Harmegnies F, Foucher JP, Fiala-Médioni A (1996b) Spatial distribution of diverse cold seep communities living on various diapiric structures of the southern Barbados prism. Progress In Oceanography, 38, 347-376.

Olu-Le Roy K (2006) Comments on: the paper of Gay et al. (2006) Seafloor facies related to upward methane flux within a giant pockmark of the Lower Congo Basin. Marine Geology 226:81-95 by Gay et al. Author's reply. Marine Geology, 232, 101-104.

Olu-Le Roy K, Caprais JC, Fifis A, Fabri MC, Galéron J, Budzinsky H, Ménach K Le, Khripounoff A, Ondréas H, Sibuet M (2007a) Cold-seep assemblages on a giant pockmark off West Africa: spatial patterns and environmental control. Marine Ecology, 28, 115-130.

Olu-Le Roy K, Cosel R von, Hourdez S, Carney SL, Jollivet D (2007b) AmphiAtlantic cold-seep Bathymodiolus species complexes across the equatorial belt. Deep-Sea Research Part I: Oceanographic Research Papers, 54, 18901911.

Ondréas H, Olu K, Fouquet Y, Charlou JL, Gay A, Dennielou B, Donval JP, Fifis A, Nadalig T, Cochonat P, Cauquil E, Bourillet JF, Moigne M le, Sibuet M (2005) ROV study of a giant pockmark on the Gabon continental margin. Geo-Marine Letters, 25, 281-292.

Pierre C, Fouquet Y (2007) Authigenic carbonates from methane seeps of the Congo 
deep-sea fan. Geo-Marine Letters, 27, 249-257.

Pop Ristova P, Wenzhöfer F, Ramette A, Zabel M, Fischer D, Kasten S, Boetius A (2012) Bacterial diversity and biogeochemistry of different chemosynthetic habitats of the REGAB cold seep (West African margin, $3160 \mathrm{~m}$ water depth). Biogeosciences, 9, 5031-5048.

Ritt B, Pierre C, Gauthier O, Wenzhöfer F, Boetius A, Sarrazin J (2011) Diversity and distribution of cold-seep fauna associated with different geological and environmental settings at mud volcanoes and pockmarks of the Nile Deep-Sea Fan. Marine Biology, 158, 1187-1210.

Roberts H, Aharon P, Carney R, Larkin J, Sassen R (1990) Sea floor responses to hydrocarbon seeps, Louisiana continental slope. Geo-Marine Letters, 10, 232 243.

Sahling H, Bohrmann G, Spiess V, Bialas J, Breitzke M, Ivanov M, Kasten S, Krastel S, Schneider R (2008) Pockmarks in the Northern Congo Fan area, SW Africa: Complex seafloor features shaped by fluid flow. Marine Geology, 249, 206225 .

Sahling H, Rickert D, Lee RW, Linke P, Suess E (2002) Macrofaunal community structure and sulfide flux at gas hydrate deposits from the Cascadia convergent margin, NE Pacific. Marine Ecology Progress Series, 231, 121-138.

Shank TM, Fornari DJ, Damm KL von, Lilley MD, Haymon RM, Lutz RA(1998) Temporal and spatial patterns of biological community development at nascent deep-sea hydrothermal vents ( $9^{\circ} 50^{\prime} \mathrm{N}$, East Pacific Rise). Deep Sea Research Part II: Topical Studies in Oceanography, 45, 465-515.

Shanks WC (1995) Rebirth of a sea-floor vent. Nature, 375, 18-19.

Sibuet M, Olu-Le Roy K (2002) Cold seep communities on continental margins: Structure and quantitative distribution relative to geological and fluid venting patterns. In: Ocean Margin Systems. Springer-Verlag, Berlin, p235-251.

Smith EB, Scott KM, Nix ER, Korte C, Fisher CR (2000) Growth and condition of seep mussels (Bathymodiolus childressi) at a Gulf of Mexico brine pool. Ecology, 81, 2392-2403.

Vincent AG, Pessel N, Borgetto M, Jouffroy J, Opderbecke J, Rigaud V (2003) Realtime geo-referenced video mosaicking with the MATISSE system. In: Proceedings of the MTS/IEEE Oceans 2003 Conference. San Diego, USA, p2319-2324. 
1 Table 1: Areas of coverage of the different assemblages calculated from the WACS

2 (2011) mosaic. Information about the distribution in soft sediments is given only for

3 faunal categories, in which the substratum type could always be identified on the

4 mosaic.

\begin{tabular}{lccc}
\hline Assemblage & Total Area $\left(\mathrm{m}^{2}\right)$ & $\begin{array}{c}\text { Within soft } \\
\text { sediments }\left(\mathrm{m}^{2}\right)\end{array}$ & $\begin{array}{c}\text { Within soft } \\
\text { sediments (\%) }\end{array}$ \\
\hline Escarpia, living & 2573 & - & - \\
Escarpia/Bathymodiolus co- & 560 & - & - \\
occurrence & 97 & - & - \\
Escarpia, juveniles & 70 & - & - \\
Escarpia, recumbent & 57 & 56.4 & $99 \%$ \\
Escarpia, senescent & 414 & - & - \\
Mytilidae, living & 67 & - & - \\
Mytilidae, shells & 88 & 86.2 & $98 \%$ \\
Vesicomyidae, living & 534 & 508.3 & $95 \%$ \\
Vesicomyidae, mixed & 633 & 549.9 & $87 \%$ \\
Vesicomyidae, shells & & & \\
\hline
\end{tabular}


1 Table 2: Areas of coverage of the different assemblages in the overlap area between

2 the Biozaire (2001) and WACS (2011) mosaics. The percentages are relative to the

3 total area $\left(4605 \mathrm{~m}^{2}\right)$ covered by both mosaics.

\begin{tabular}{lccccc}
\hline Assemblage & $\begin{array}{c}\text { Biozaire } \\
\left(\mathrm{m}^{2}\right)\end{array}$ & $\begin{array}{c}\text { Biozaire } \\
(\%)\end{array}$ & $\begin{array}{c}\text { WACS } \\
\left(\mathrm{m}^{2}\right)\end{array}$ & $\begin{array}{c}\text { WACS } \\
(\%)\end{array}$ & Trend \\
\hline Escarpia, living & 716 & $15.5 \%$ & 782 & $17.0 \%$ & $+1.5 \%$ \\
Escarpia/Bathymodiolus & 207 & $4.5 \%$ & 268 & $5.8 \%$ & $+1.3 \%$ \\
co-occurrence & 25 & $0.5 \%$ & 28 & $0.6 \%$ & $+0.1 \%$ \\
Escarpia, juveniles & 79 & $1.7 \%$ & 60 & $1.3 \%$ & $-0.4 \%$ \\
Escarpia, recumbent & 70 & $1.5 \%$ & 95 & $2.1 \%$ & $+0.6 \%$ \\
Escarpia, senescent & 194 & $4.2 \%$ & 207 & $4.5 \%$ & $+0.3 \%$ \\
Mytilidae, living & 2 & $0.04 \%$ & 14 & $0.3 \%$ & $+0.3 \%$ \\
Mytilidae, shells & 23 & $0.5 \%$ & 27 & $0.6 \%$ & $+0.1 \%$ \\
Vesicomyidae, living & 141 & $3.1 \%$ & 199 & $4.3 \%$ & $+1.2 \%$ \\
Vesicomyidae, mixed & 112 & $2.4 \%$ & 125 & $2.7 \%$ & $+0.3 \%$ \\
Vesicomyidae, shells & & & & & \\
\hline
\end{tabular}




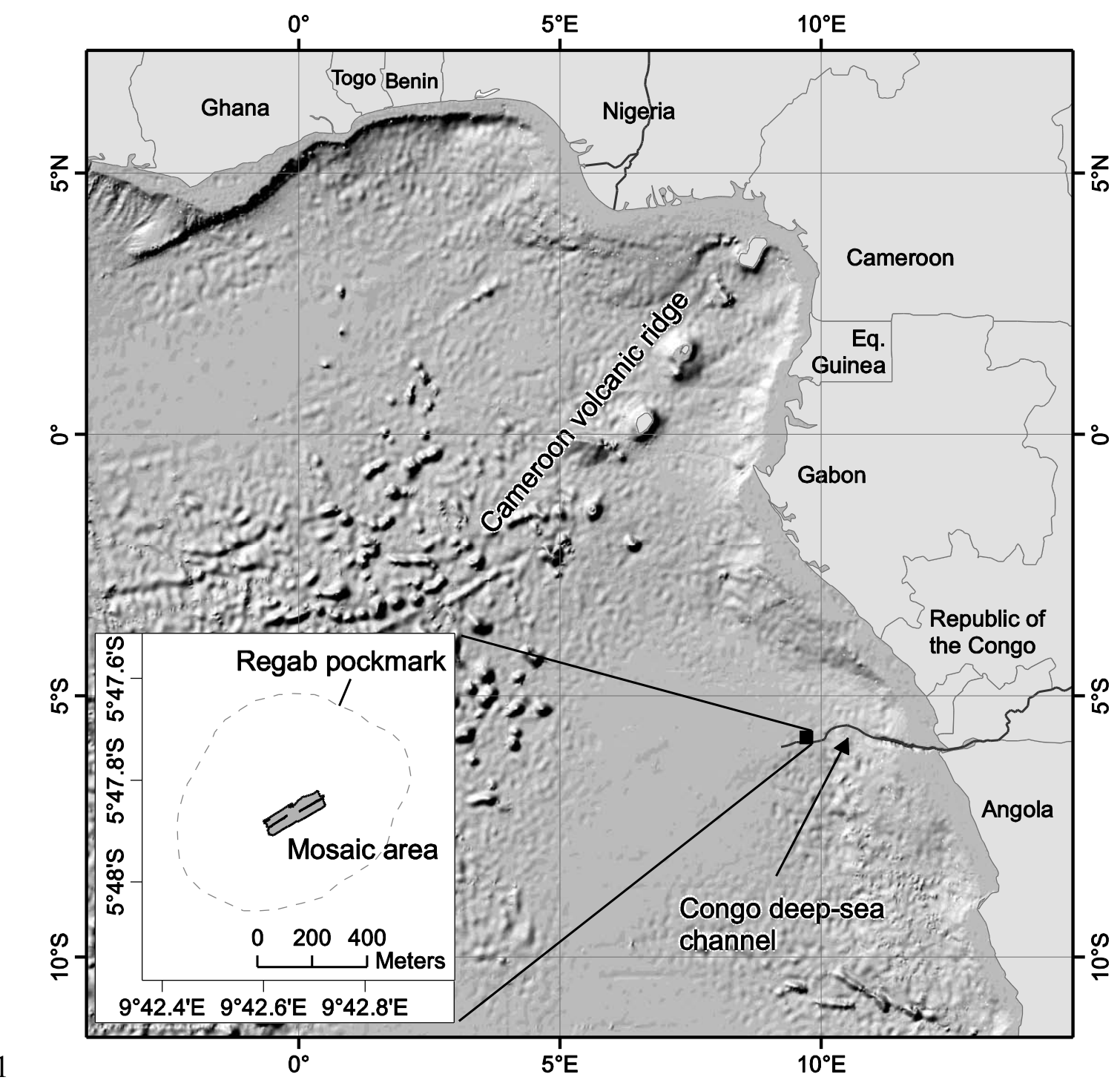

2 Fig 1: Location of the Regab pockmark; the insert map shows the approximate outline 3 of the pockmark and the mosaic area. 


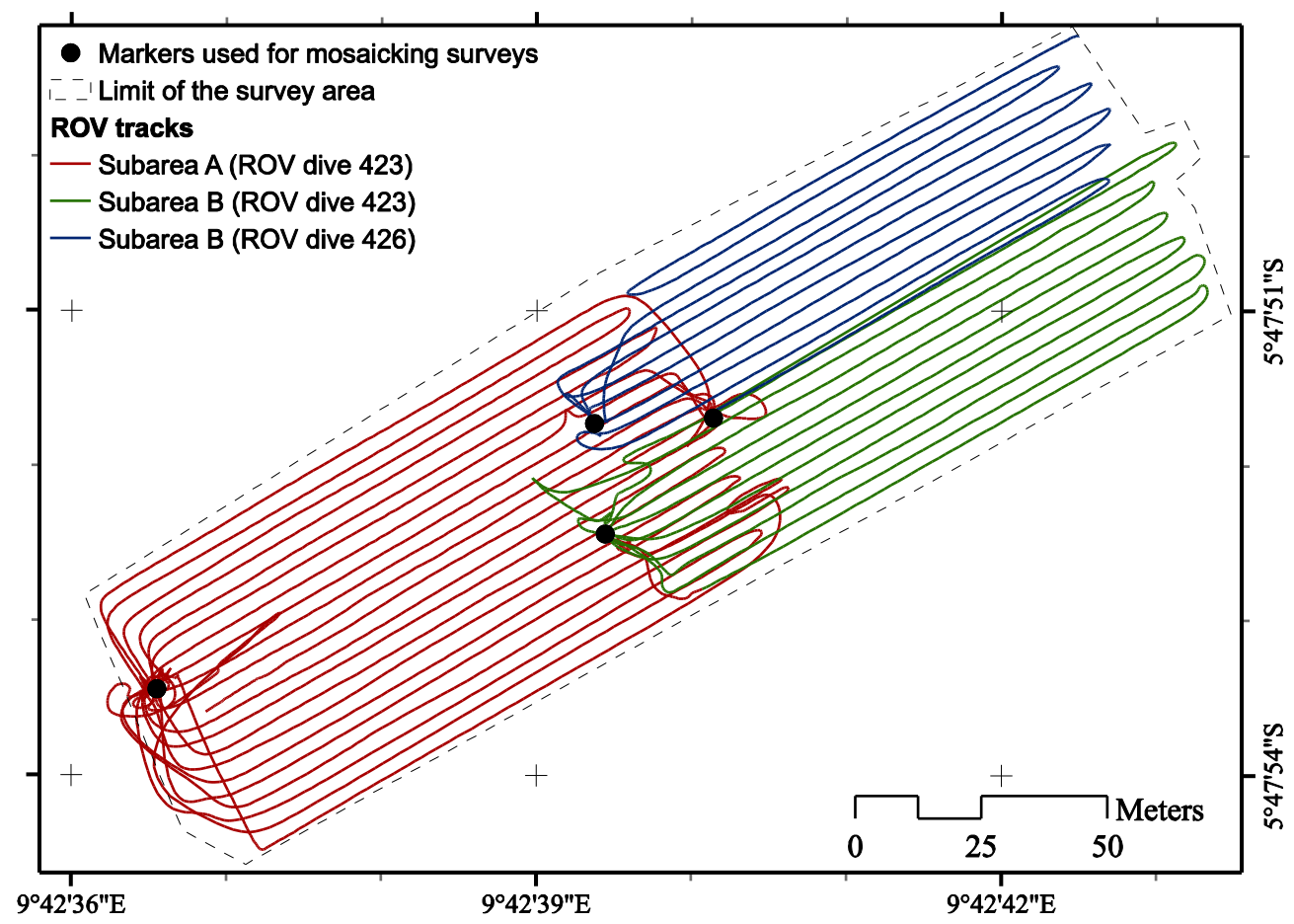

2

Fig 2: ROV navigation of the WACS mosaicking survey showing the distribution and 4 the overlap of the two subareas (A and B), as well as which areas were surveyed 5 during the two mosaicking dives (423 and 426). The navigation data was regularly 6 reset onto known markers (black dots) to constrain global drifting error. 


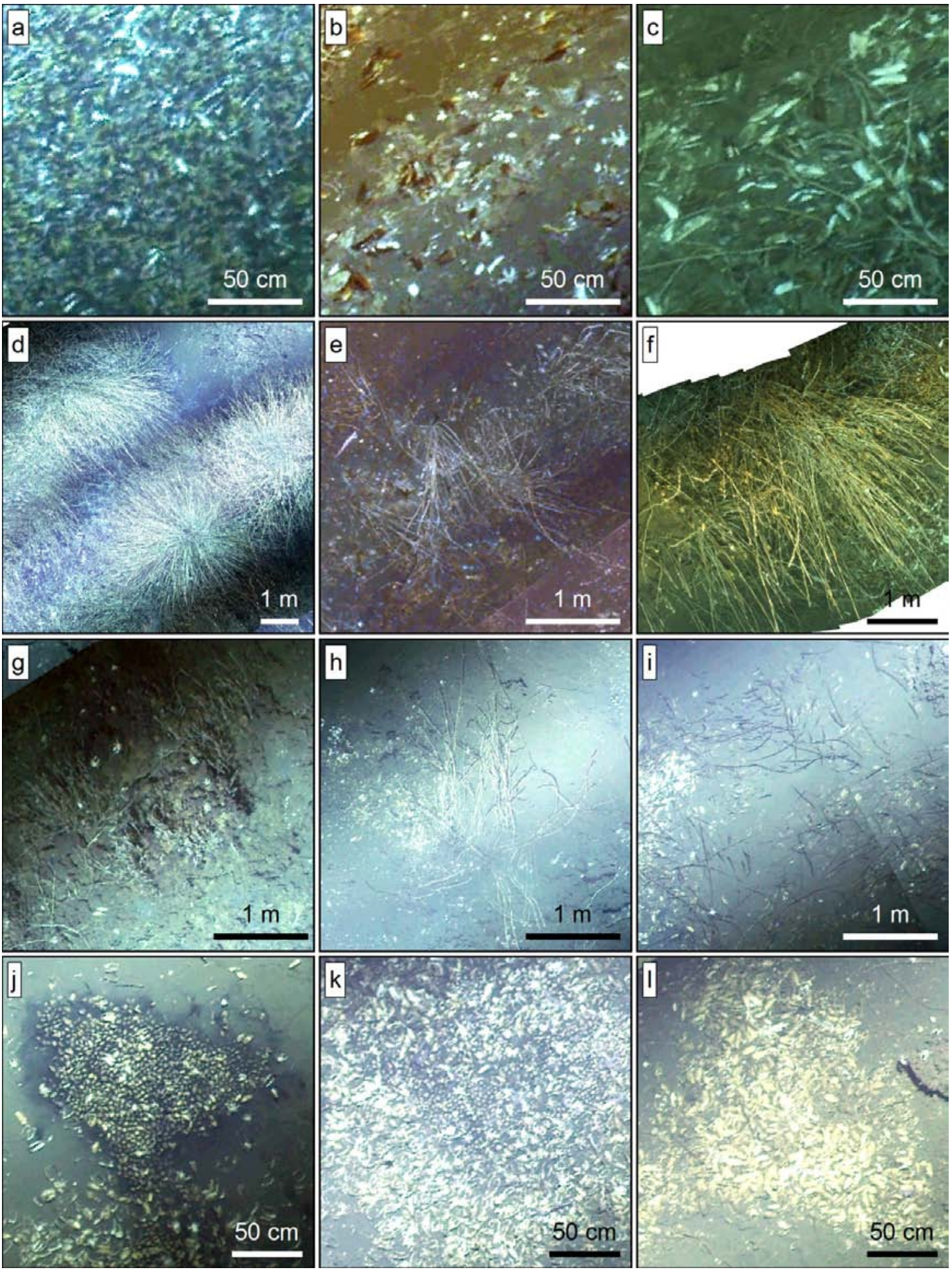

4 Fig 3: Excerpts of the WACS mosaic illustrating the different faunal categories; (a) 5 Mytilidae, dense; (b) Mytilidae, sparse; (c) Mytilidae, shells; (d) E. southwardae, 6 dense; (e) E. southwardae, sparse; (f) E. southwardae-Mytilidae co-occurrence; (g) E. 7 southwardae, juvenile; (h) E. southwardae, recumbent; (i) E. southwardae, senescent; 8 (j) Vesicomyidae, living (in the black sediments); (k) Vesicomyidae, living/dead 9 (mixed); (l) Vesicomyidae, shells. Images taken by ROV Victor 6000 (C) Ifremer, 10 WACS 2011). 


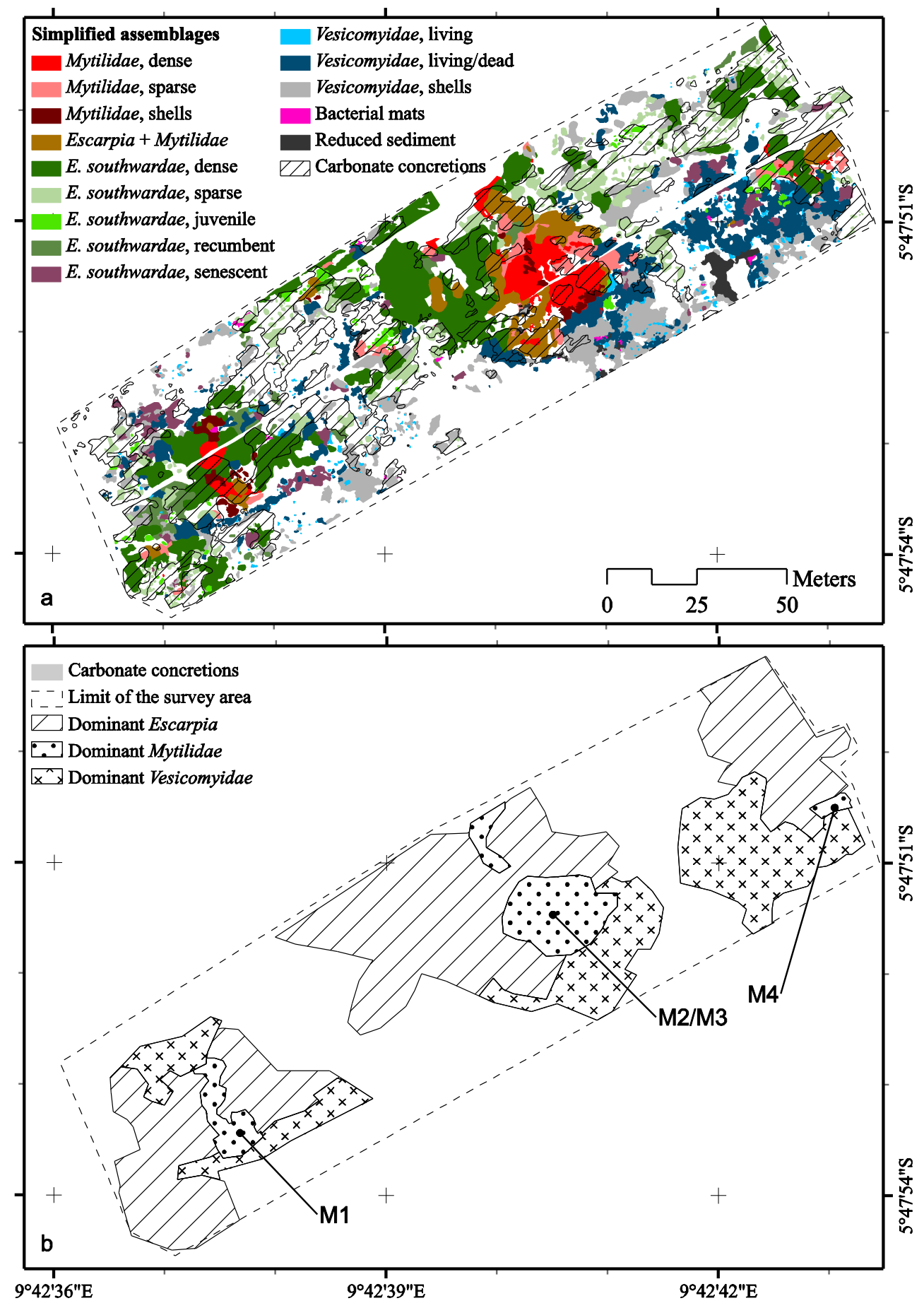

3 Fig 4: (a) Distribution of the main faunal categories and carbonate concretions based 4 on the WACS mosaic; (b) Simplified areas of distribution of the main types of fauna 5 according to the WACS mosaic; the remaining 'blank' part of the survey area 6 corresponds to the 'areas of low fauna presence' (see text). 


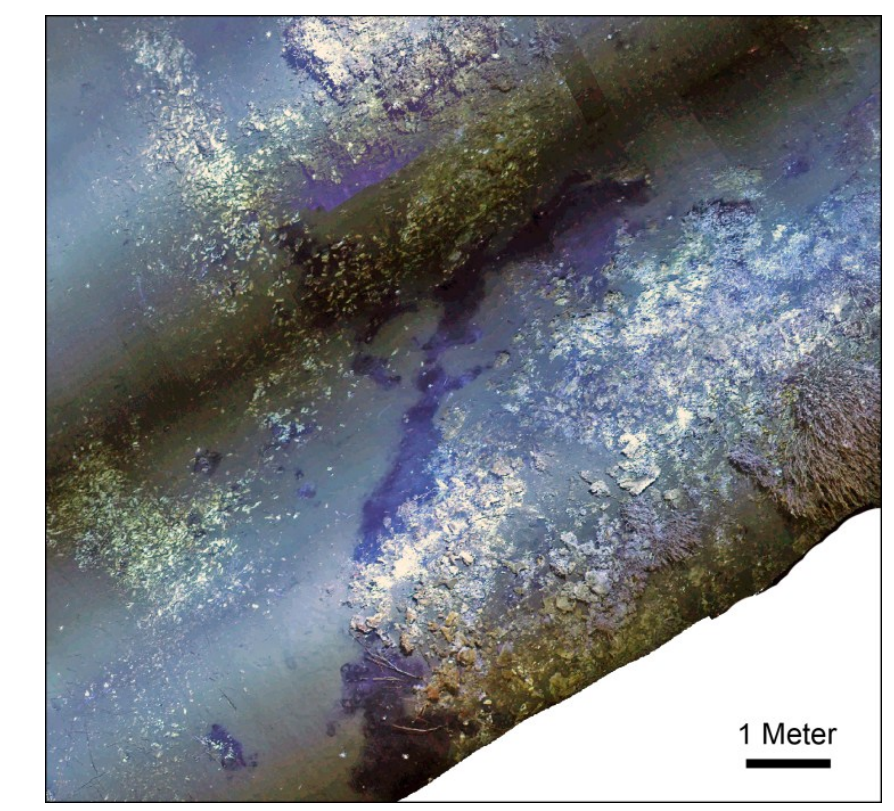

3 Fig 5: Excerpt from the WACS mosaic showing a limit between carbonate crusts 4 (right) and soft sediments (left); juvenile vestimentiferans are visible on the right and 5 fields of vesicomyid clams can be seen in the sediment on the left. A band of reduced 6 sediments occurs along the border of carbonate crusts. Images taken by ROV Victor 76000 (C) Ifremer, WACS 2011).

8 


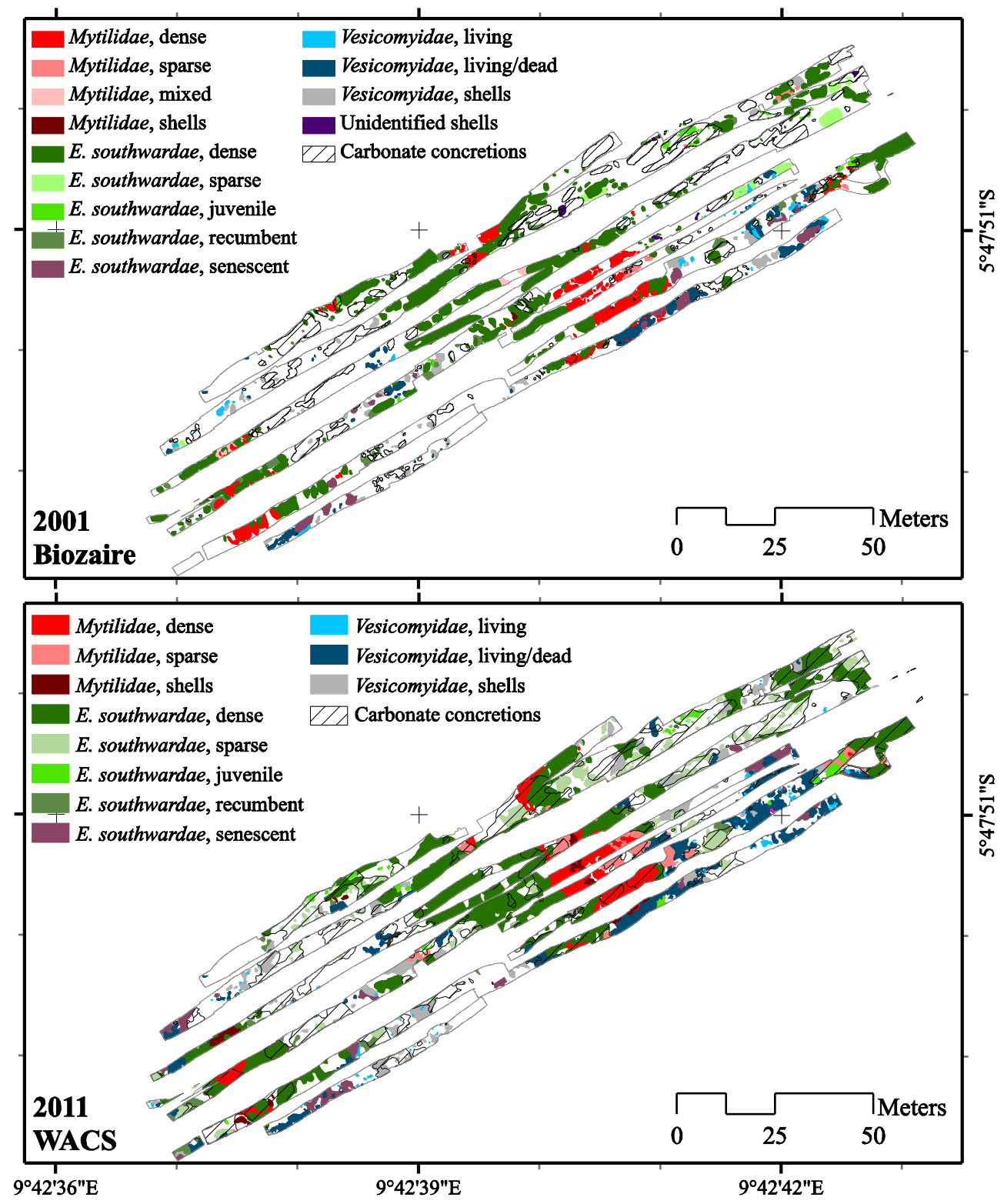

3 Fig 6: Distribution of the main faunal categories and carbonate concretions in the area 4 of overlap between the Biozaire (2001) and the WACS (2011) mosaics. 

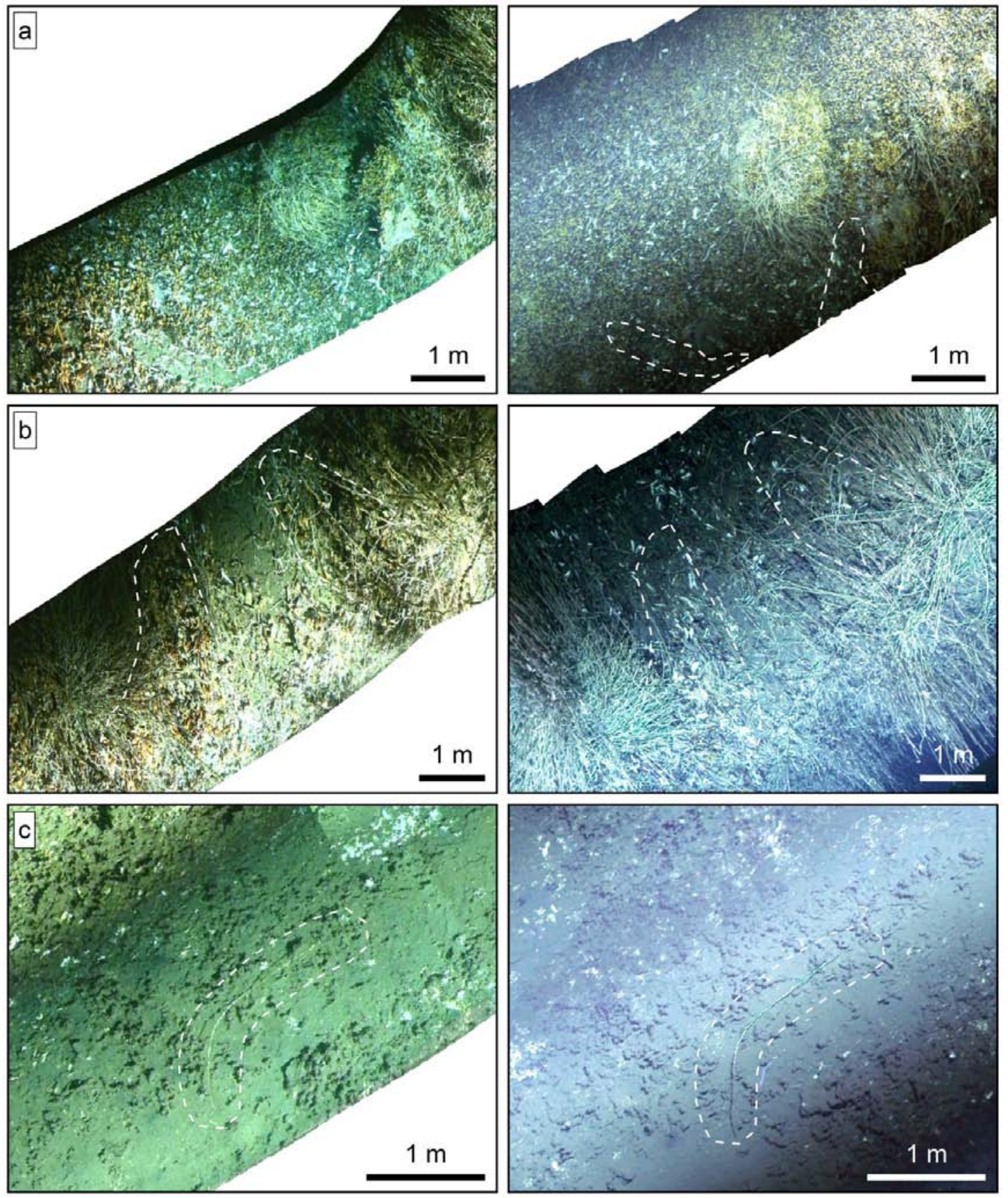

2 Fig 7: Images taken from the Biozaire (left) and WACS (right) mosaics, representing 3 almost the same areas of the seafloor; (a) at M2, some areas previously devoid of 4 mussels are now fully colonized by mussels; (b) at M1, small beds of living mussels 5 on the Biozaire have been replaced by mussel shells on the WACS mosaic; (c) a 6 recumbent tube of vestimentiferan showed no change in size and position between 72001 and 2011. Images taken by ROV Victor 6000 (C) Ifremer, Biozaire 2001 and 8 WACS 2011). 

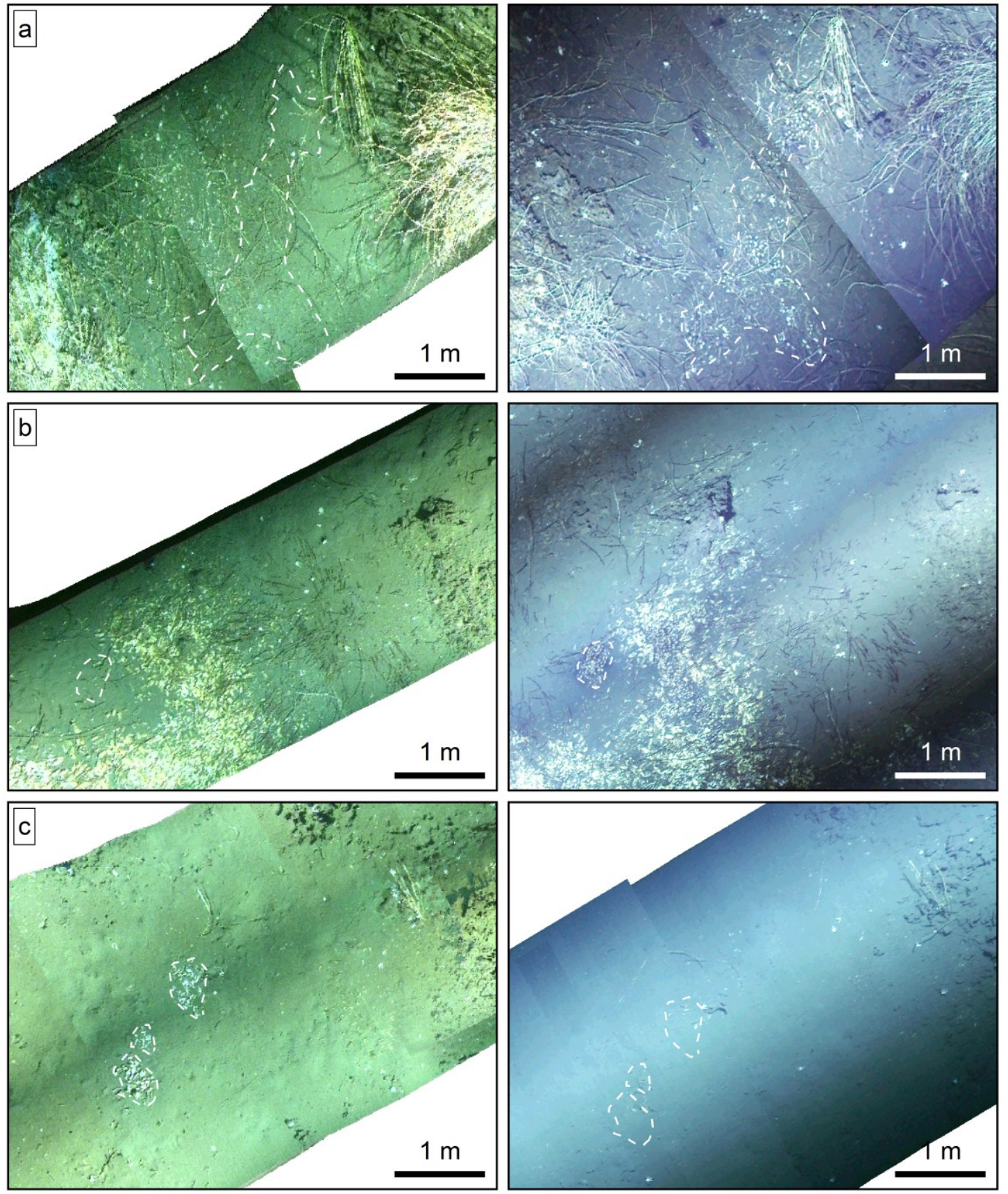

2 Fig 8: Images taken from the Biozaire (left) and WACS (right) mosaics, representing 3 almost the same areas of the seafloor; $(a, b)$ new patches of vesicomyids that did not 4 exist at the time of the Biozaire cruise; $b$ also shows that the patch of dead clams has 5 been partly re-colonized; (c) a patch of mixed vesicomyids almost disappeared under 6 sediment cover. Images taken by ROV Victor 6000 (C) Ifremer, Biozaire 2001 and 7 WACS 2011). 


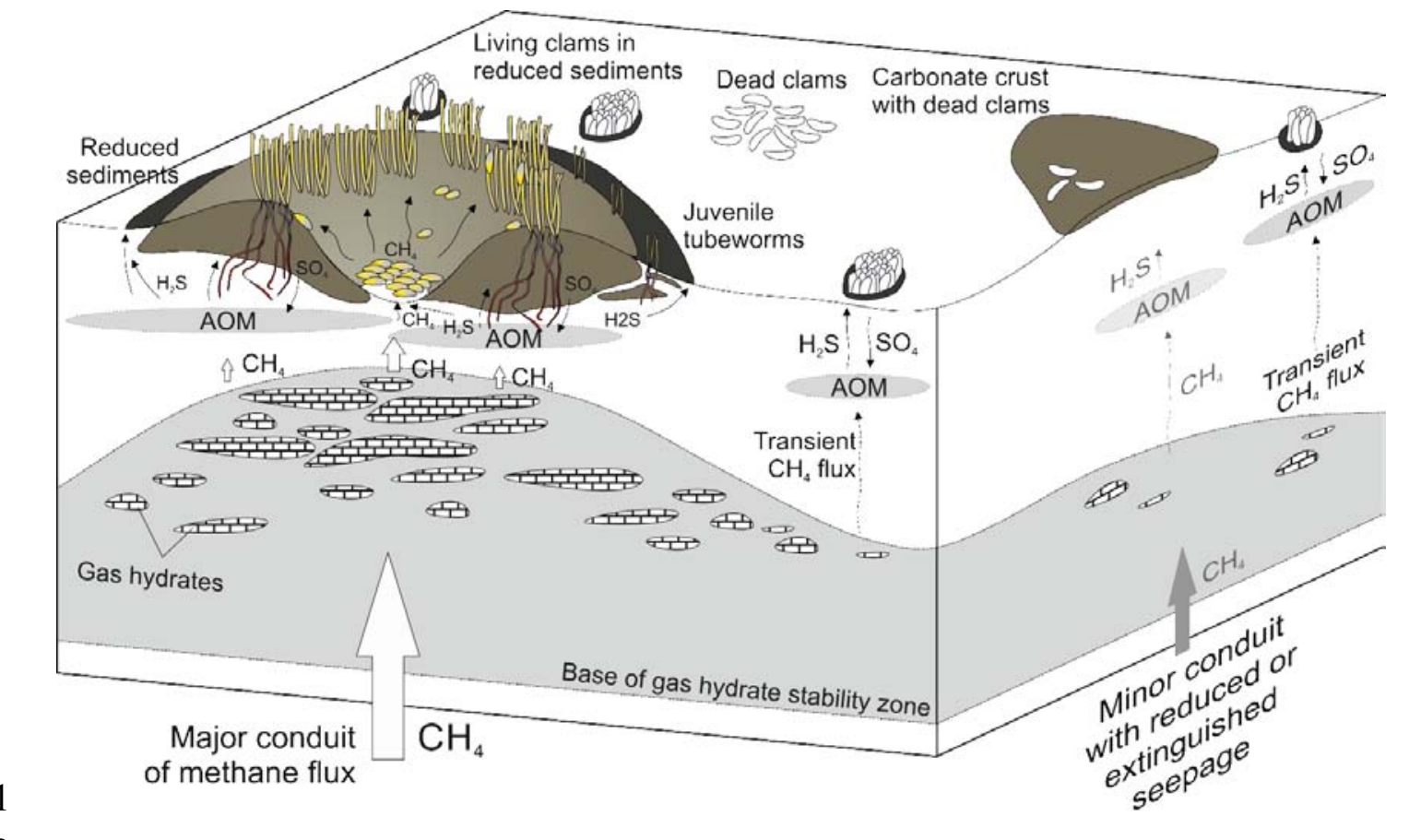

3 Fig 9: Summary schematic model (not to scale). The main aggregations are distributed 4 in concentric patterns with the mussels in the middle, then the tubeworms on thick 5 concretions, and finally the vesicomyid clams in the sediments around. Mussels are 6 present in an area of intense flux with significant release of methane to the water 7 column. A transition zone is observed where mussels are present at the bottom and on 8 the tubes of the vestimentiferans. Vestimentiferans are present on carbonate 9 concretions but reach the sediments with their roots. Through sulfate release, they 10 maintain the AOM and the sulfide production. Juvenile tubeworms are distributed near the limit of the crusts where the sulfide fluxes from the sediments are likely higher. The presence of dark reduced sediments around the concretions indicate that part of the methane and sulfide fluxes are redirected from under the crusts towards more sulfate-rich zones where AOM occurs. Populations of vesicomyid clams occur 15 in the sediments around. Their patchy distribution suggests that it is controlled by 16 discrete and transient fluxes from below. 